\title{
THE TRIRADIATE AND OTHER FORMS OF NITZSCHIA CLOSTERIUM (EHRENBERG) WM. SMITH, FORMA MINUTISSIMA OF ALLEN AND NELSON
}

\author{
By Douglas P. Wilson
}

Naturalist at the Plymouth Laboratory

(Text-figs. I-9)

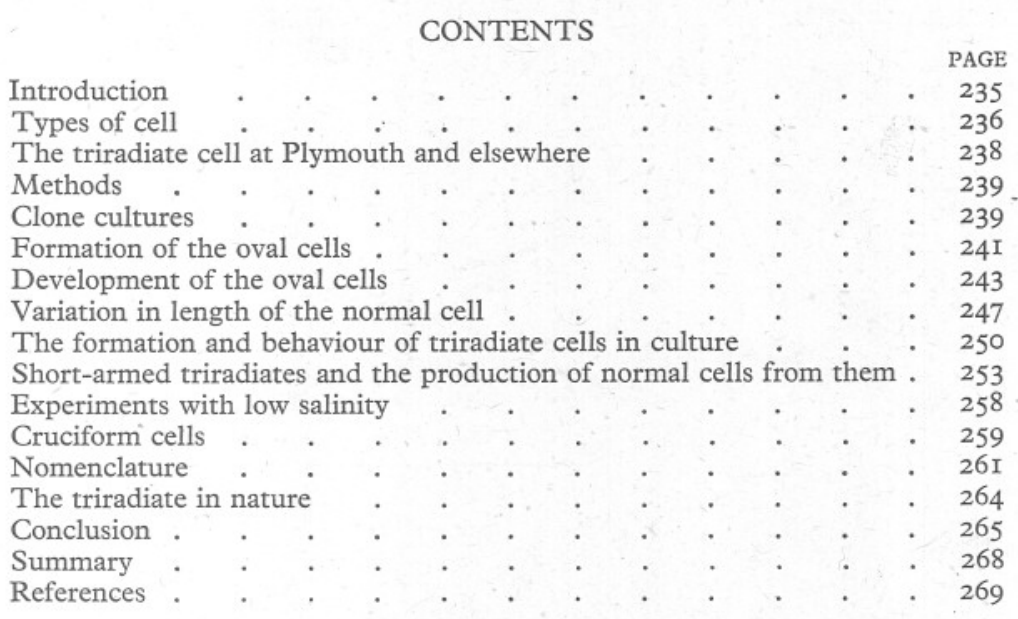

\section{INTRODUCTION}

The diatom forming the subject of these notes was first isolated by Allen \& Nelson (I9IO); it has been kept in culture for over thirty years. Owing to the ease with which it may be cultured this particular species of Nitzschia has proved of great value for experimental work on diatom physiology, and it has been of no less value as a food for marine larvae in captivity, enabling much embryological work to be accomplished. From the Plymouth Laboratory subcultures have been distributed to many research institutions in this country and abroad; in some places stocks are still maintained. It is the policy of the Plymouth Laboratory always to have available healthily growing stocks which may be drawn upon at any time by workers throughout the world.

It is surprising that with this widespread use so little appears to be known about the general natural history of the species in culture, especially as regards morphology and reproduction. When the Plymouth stocks came into my 
care interest in these problems was stimulated by the facts that the majority of the cells presented a three-rayed or triradiate appearance, and that the normal or fusiform cells seemed to be dying out. It was evidently desirable to reestablish cultures of the normal form, especially as the triradiate seemed to be an unsatisfactory shape for larval mouths and gullets. Knowledge was also needed of the relationship of the triradiate to the normal cell, as was also a better understanding of the sequence of events in the stock cultures. To some extent this has now been achieved and, although there is much still to seek, these notes are presented as a partial solution of the many problems raised by this remarkably variable species.

\section{TyPeS OF CeLL}

In general three main types of cell are to be observed: the normal, the triradiate and the oval.

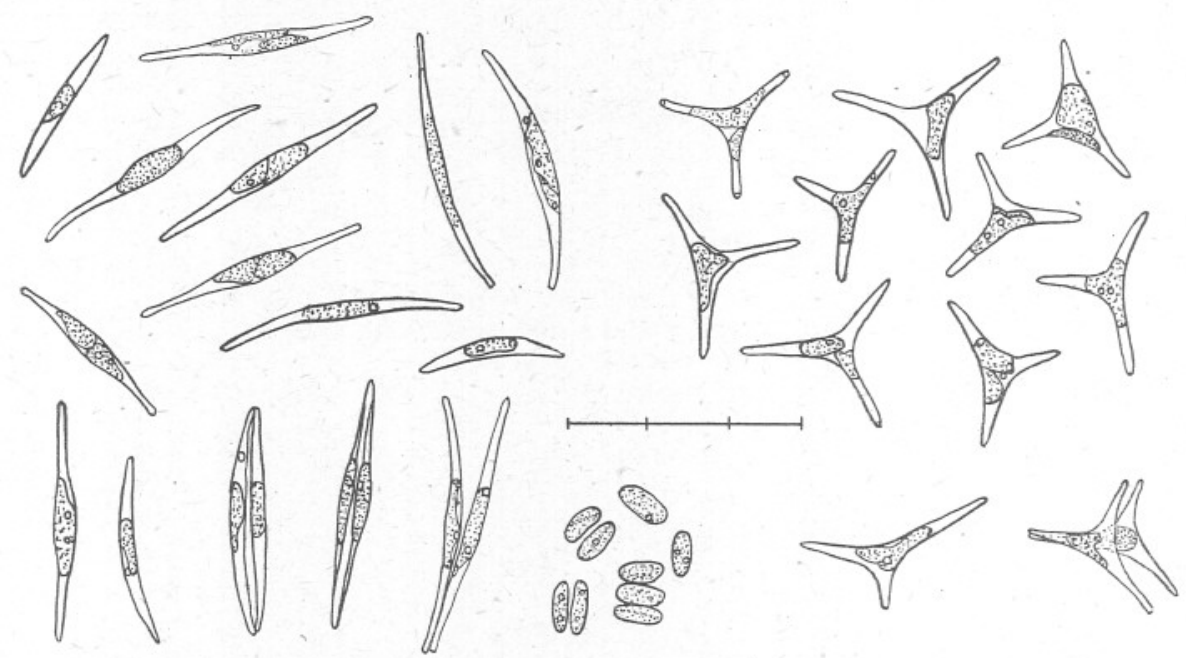

Fig. I. Nitzschia closterium forma minutissima. Typical normal, triradiate and oval cells from different cultures drawn on various dates. Division stages are included and one shortarmed triradiate is shown. Each division of the scale represents ro $\mu$.

The Normal Cell. This is a spindle-shaped almost fusiform cell, straight or more usually slightly curved, $25-35 \mu$ long, though sometimes shorter. It is rare to find cells longer than $35 \mu$. Approximately the middle third of the spindle is swollen, each end tapering off to a rounded point (Fig. I). It will be necessary to refer very frequently to these tapering prolongations, the rostra, rostral prolongations, beaks, horns, etc., as they are variously called by diatomists. They are, of course, prolongations of the valves and are not true spines. In what follows they will be referred to as 'arms'. The swollen central portion contains, in addition to the nucleus, the chromatophores, one to two, which in a dim light expand into and down the arms. Besides the chromato- 
phores, more especially in old cultures in which growth has ceased, are to be seen one or more refringent globules stainable with Scarlet Red and evidently of a fatty nature. At the bluntly rounded and often slightly swollen extremities of the arms there is frequently an appearance as of polar nodules. This may, however, be an optical effect due to overlap of the valve ends; the effect sometimes disappears with increased magnification. The individual valves are exceedingly difficult to make out, but in very old cultures, with all the protoplasmic contents contracted, the valves tend to separate and can then be seen (Fig. -3 B, a). The girdle pieces seem to be much thinner than the valves. In healthy cells the girdle pieces are so closely apposed that in transverse section-sections have been cut as thinly as $2 \mu$-the cell wall under the highest powers gives the appearance of a complete uninterrupted ring. I have not been able to satisfy myself that I have seen any of the usual valve markings of the Nitzschioideae, the keel and canal raphe or the carinal dots, although my optical equipment resolved all the usual test diatoms with the single exception of Amphipleura pellucida. Only in some gently incinerated specimens mounted in Sirax (a medium of high refractive index) were to be seen what might possibly be the keel and raphe with some slight suggestion of carinal dots, but it was impossible to be certain of the identity of the structures seen; they might very well have been artifacts. This species of Nitzschia is minute, and its size is a great handicap on all observations concerned with structural details and also makes the handling of individual cells a task of considerable difficulty.

The Triradiate Cell. This closely resembles the normal except that it has three arms instead of two. The three angles enclosed by the arms are rarely equal and there is much variation between individuals. On the whole the arms are shorter than those of the normal form, being 6-8 $\mu$ long in good-sized. specimens as compared with about Io $\mu$ long in the normal. They are often unequal in length. Whilst there may occasionally be three chromatophores one to two is the usual number. It would be interesting to know how the keel and raphe, if present, are arranged, but it has not been possible to make them out. Some incinerated specimens mounted in Sirax showed what might have been these structures running between the bases of two of the arms and ignoring the third, but this appearance could have been caused by folds due to collapse of the cell wall and they were not visible in all specimens.

The Oval Cell. This cell has no arms, and as the name suggests is roughly oval in shape. It is about $8 \mu$ long and $3-4 \mu$ broad, almost the whole of the space inside the cell wall being taken up by the chromatophores of which there are one or two. At each end there is sometimes a refringent globule which appears to be a product of photosynthesis. The cell wall is of the same appearance and thickness as that of normal and triradiate cells, and presumably is made up of valves and girdle pieces although these have not definitely been distinguished. 


\section{The Triradiate Cell at Plymouth and Elsewhere}

During the long period from first isolation until 1936 the stock cultures at Plymouth were under the care of the then Director, the late Dr E. J. Allen, who with the late $\mathrm{Mr} \mathrm{E}$. W. Nelson had made the original isolation from the sea. Dr Allen told me (in I942) that although he had seen occasional triradiates in his cultures they were never, to his knowledge, very numerous. However, $\mathrm{Mr}$ Clifford Dobell writes to inform me that he remembers that in the winter of I9IO-II he had occasion to examine some old exhausted cultures which Dr Allen had himself left at the Royal College of Science, South Kensington, during the previous summer, and he was surprised to find 'that they all contained enormous numbers of "triradiate" forms the like of which I had never seen previously'. Thus triradiates were present, and could become numerous, in the early days of the cultures and are not a product of a longcontinued artificial environment. Dr F. Gross remembers often noticing them in the Plymouth cultures whilst they were in his care for a short period in 1936-7. In the summer of 1939, when my own attention was first attracted to the problem, triradiate cells accounted for over $90 \%$ of those present. The cultures were perfectly healthy and not noticeably contaminated with bacteria or other organisms. Later on these stocks became almost completely triradiate, although by the summer and autumn of I94I normal cells were once more fairly abundant. The history of this period is studied in detail below.

Similar happenings to those at Plymouth have taken place elsewhere with cultures originally derived from Plymouth stocks. Some account of the stock cultures at Hull and their comparison with those at the Plymouth Laboratory has already been published (Wilson \& Lucas, 1942) and will be more fully discussed later in this paper. From Woods Hole, Massachusetts, Dr Bostwick $\mathrm{H}$. Ketchum informs me that his Nitzschia cultures had been derived from Plymouth about 1930, and that when he started work on the species in I934, $5-10 \%$ of the culture consisted of triradiate forms. In that year he succeeded in isolating a single normal cell, and in cultures grown from it no reoccurrence of the triradiate had been observed as late as the summer of I94I. The original culture containing the triradiates was lost. Also in America, Barker (I935) records experimental work on Nitzschia cultures originally derived from Plymouth and mentions 'distinctly oval cells and cells shaped like a threepointed star' but does not figure them. In order to obtain bacteria-free cultures he grew the diatom in a succession of plates of solid agar, finally inoculating liquid media after elimination of the bacteria. From an examination of the agar plates he found that 'all three cell shapes are interconvertible'. In successive plates oval cells became more numerous and 'after the fifth transfer only oval-shaped cells could be found. When these cells are inoculated back into liquid media there is a gradual reversion during several transfers to spindle-shaped cells. The oval cells do not entirely disappear. The star-shaped cells have never yet reappeared in their original abundance. They can be 
observed only rarely in a dense culture and represent not more than one cell out of 100,000. These observations demonstrate clearly that these variously shaped cells of $N$. closterium belong to a genetically pure line.' I am indebted to Prof. A. C. Hardy for calling my attention to this reference after I had already made substantially the same observations using liquid media.

\section{Methods}

The cultural methods of Allen \& Nelson (I910) and of Gross (1937) were followed. The stock cultures were always grown in the former's 'Miquel sea water', the 'Erdschreiber' formula of the latter being employed only for special experiments. There is in practice a little difference between the two media in that the Erdschreiber contaminates more readily with other organisms; cells grown in it are, in general, slightly larger and better formed than those in the traditional Allen-Miquel sea water.

Some single cells were picked out with fine pipettes under a high-power dissecting microscope, but they proved too minute for much work to be done in this way. It was more practicable to select small clusters of cells of the same type, especially ovals which tend to agglomerate, and more cultures were started from such clusters than from single cells. It was relatively easy to make certain that such a cluster contained only one type of cell, for it could be examined on a slide under a cover-glass with a high-power objective, subsequently being washed through several changes of sterile media. Single cells treated in this way were nearly always lost in the process.

Another method of separating types of cell was greatly to dilute a drop of the appropriate culture and then to inoculate sterile media in shallow Petri dishes. After a few days clusters of cells would be found scattered over the bottom of the dish, each cluster derived from the growth of a single cell. A cluster of the type needed was then removed with small risk of contamination from neighbouring clusters. The drawings were made with a camera lucida. They are merely outlines which do not convey the transparent delicacy of the living cells.

\section{Clone Cultures}

In July 1939 a single triradiate cell was, after several attempts, successfully isolated into a watch-glass of Erdschreiber. It grew quickly, giving rise to a small group of triradiate cells and to none of any other kind. These cells were transferred to a small flask of Erdschreiber, and from this some days later a large flask of Allen-Miquel sea water was inoculated, so establishing a clone of triradiates which has been regularly subcultured ever since. In what follows this clone will be referred to as Series III.

About the same time one of several attempts to isolate a single normal cell was successful, and from it, in a similar manner, a clone of normal cells was obtained. This clone was divided into two series of subcultures, Series I and Series II, which were ever afterwards kept separate. A slight difference of 
treatment marked their inception. Some minute flagellates had been observed in the Erdschreiber in which the single original cell had grown, and therefore, whilst Series I was inoculated directly into a large flask of Allen-Miquel sea water, the initial cells of Series II were washed for a minute or so in a dilute solution of iodine in sea water. The flagellates were thereby killed, but the only observed effect on the diatoms was to check for a few days their growth as compared with Series I. In the latter series the flagellates soon died out, probably because the Allen-Miquel sea water was an unsuitable medium for them.

The subsequent history of the clone cultures will be discussed in detail later. Here it is sufficient to state that for some months, though regularly subcultured, they remained fundamentally true to type, except that oval cells were produced. This was true not only for healthy actively growing subcultures, but also for old exhausted subcultures kept for several months after finishing their growth. Some of these old cultures eventually became heavily infected with bacteria, flagellates and moulds before they were finally discarded.

It was in July that the clone cultures were first formed, and it was in the following January that the first regular normal cells were seen in Series III and the first regular triradiates in Series I and II, although some hint of their coming appearance had been noted as early as the end of October. At that time a few triradiates each with one or two reduced arms had been observed in Series III, whilst in the clone normal series a dividing three-cornered oval was seen in one culture. In the old infected cultures some misshapen cells could be found, but it did not appear that these were producing cells of the alternate form and it did not seem that overcrowding or unhealthy conditions were initiating a change-over from one type of cell to the other. It had at one time been thought that the triradiate might be a product of unhealthy cultural conditions, but this was not supported by observation.

The first normal cells in Series III and the first triradiates in Series I and II were very rare, especially in Series II, where it was often impossible to find any during the first two years. The proportion of normal cells to triradiates in Series III increased much more rapidly than did the proportion of triradiates to normals in Series I and II. Thus an estimation in June I94I showed that in Series III (see Table V) I $\cdot 2 \%$ of the cells were normal, a proportion that had by November that year increased to $40 \%$. In June I94I Series I showed (Table V) much less than I \% of the cells triradiate, whilst in Series II none appeared in the count. However, by February the proportion in Series I had risen to $5.4 \%$ and thereafter steadily increased. In Series II a significant proportion appeared about the same time and also increased, though much more slowly. Figures showing the subsequent changes in the proportions are set out in Table V. 


\section{Formation of the Oval Cells}

In practically all cultures are to be found the armless oval cells already described. They are most abundant on the bottom and sides of the flask, adherent in sheets, sometimes mixed with armed cells of both sorts. They secrete a mucus-like substance which stains deeply with methylene blue. When examined on a slide they show, if obtained from a healthy growing culture, gliding movements over the substratum and a group of cells soon scatters. Normals and triradiates show similar movements.

Oval cells derive, by division, from armed cells of both kinds. Stages in their production are often common in the cultures, and typical ones are shown

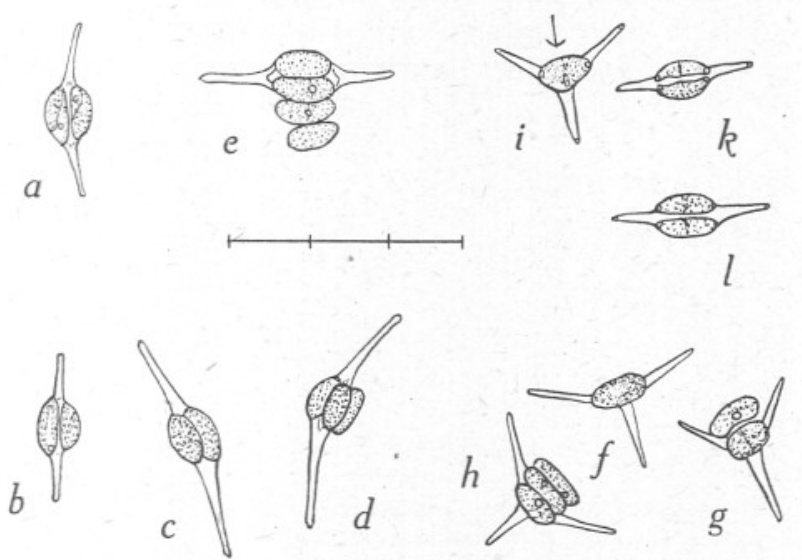

Fig. 2. Stages in the formation of oval cells from normal and triradiate cells. $a-c$, formation from normal cells; $d, e$, more than two ovals arising from one normal; $f-h$, formation from triradiates, including multiple oval formation; $i$, a stage in the formation from a triradiate cell which is drawn again at $k$ as viewed in the direction of the arrow; $l$, another cell viewed as in $k$. The cells are from various cultures on different dates. Each division of the scale represents Iо $\mu$.

in Fig. 2. Details of the process are not clear; the behaviour of the nucleus and of the cell wall during division have not been made out in spite of considerable effort directed to that end: the structures are too minute to be seen clearly in detail. It seems that ovals are merely the product of division stages in which only one of the two daughter cells retains the arms. An armed cell about to give rise to an oval becomes very swollen in the central chromatophore region prior to division, and at the same time probably shortens in overall length. At any rate such cells are in general shorter than the longer cells in a culture. The oval frequently adheres for a time to the armed cell, often itself dividing so that two or more ovals all attached to a single armed cell is by no means an uncommon sight. It may be that the armed cell itself continues to bud-off ovals; this is suggested by finding groups of cells such as those shown in Fig. 2, $e$, where with two ovals already outside the frustule the valves are distended by two ovals still within. It is unfortunate that attempts to grow 
the diatom in cavity slides or in hanging-drop cultures, with a view to following the divisions of individual cells, met with no success. However, the different stages found in the cultures leave no doubt that oval cells are produced from armed cells by some form of direct division.

The conditions under which oval-cell production is initiated are not completely known. At one time it was thought that their most common occurrence on the bottom and sides of a flask indicated that contact with a substratum stimulated their formation, but cultures grown on a shaking apparatus, which ensured that no cell was allowed to sink and rest, produced them no less readily. In these shaken cultures the oval cells were scattered throughout the culture, both singly and in little clumps, the clumps containing armed cells as well. The ovals in the shaken cultures were very numerous; it should be noted that they were grown rather quickly in a good light. Overcrowding does

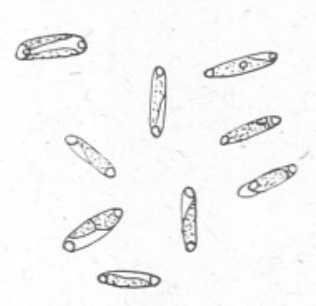

A

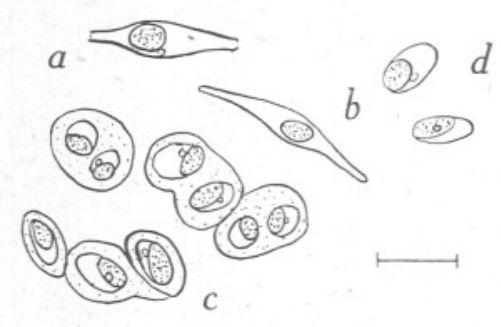

B

Fig. 3. A. Oval cells from a culture where ovals were multiplying rapidly to form more ovals. The cells showed slight elongation and the chromatophores did not completely fill them. The globules were products of photosynthesis and the cells were moving about actively. B. Cells from an old exhausted culture with much contracted chromatophores. $a$ and $b$, normal cells, in $a$ the valves have moved apart; $c$, oval cells embedded in a mucilaginous substance; $d$, free oval cells. The scale represents Io $\mu$.

not appear to be a contributory factor in oval production because they frequently occur in sparse and actively growing cultures. On the whole they appeared more readily in Erdschreiber than in Allen-Miquel sea water, though there were exceptions to this. This might indicate that good cultural conditions are favourable to their production. They appear more definitely in cultures set in a good light, such as that near a north window, and they may be absent, or almost absent, in cultures grown in a dimmer light. This observation was confirmed by a series of simple experiments. It was significant to find that in cultures placed well back from a north window, and grown without disturbance, ovals were markedly abundant in patches on the sides of the flasks away from the window where the light had focused by refraction through the convex fronts. There seems little doubt that a good light (but not direct sunlight which is distinctly harmful) is essential for active oval production, and that in a relatively dim light few, or none, are formed.

It will be remembered that Barker's cultures in solid agar (see p. 238) after the fifth transfer contained only oval cells. This may indicate that a solid 
medium is unfavourable to the production of elongated valves, but Nitzschia grown in agar in this laboratory (by Dr S. P. Chu, to whom I am indebted for some of his material) showed no special tendency to oval production and the cells were fully normal in shape. Perhaps Barker's results were due as much to good lighting conditions as to anything else.

Oval cells divide and give rise to more ovals. This sometimes goes on for a long period, and small clusters of ovals isolated to fresh media will often produce vast numbers of oval cells with a complete absence of armed forms. The ovals may, however, be slightly elongated and the chromatophores not quite so tightly packed as in newly formed ovals (Fig. 3A). This may continue through several stages of subculturing. Oval cells thus cannot be mistaken for resting spores, although in old exhausted cultures (Fig. 3 B) they secrete thick mucus-like coats, deeply stainable with methylene blue and gentian violet, and in this condition remain dormant for a long time until supplied with fresh media.

Development of the Oval Cells

Clusters of oval cells have several times been isolated and grown in fresh media. The experiments fall into two groups of which the first concerns ovals removed from the clone triradiate (Series III), some details of which will now be given.

In eight experiments small clusters of oval cells were removed from subcultures of Series III and placed in fresh media. Each cluster and the drop of medium containing it were most carefully examined to ensure that only oval cells were present. Six of these clusters eventually produced normal cells and no triradiates; one other produced normals and triradiates in about equal numbers; the remaining one produced a few triradiates among a very large number of normals. In all the experiments the ovals multiplied before and after producing armed cells. In the first experiment, made in March I940, fully sized normals were produced within a week. The second experiment, when roughly equal numbers of normals and triradiates were produced, was made in the following July; armed forms did not appear for about a fortnight when the ovals, as described later, gradually grew arms (Table II, Series 'U'). The remaining six experiments were made simultaneously in November I940 (Table I, Series ' $T$ '). In these, apart from slight elongation, the ovals multiplied in the armless condition through several stages of subculturing until June and July I94I when armed cells first appeared in three of them, the flasks constituting the other three experiments having been lost by enemy action during the preceding March, at a time when they contained ovals only.

In addition to the foregoing experiments in which oval cells were definitely isolated from all other kinds some tests were made in which the clusters of ovals, picked out from Series III, contained a few triradiates as well. No normals were present in these clusters. In seven such tests, made in April and May I940, the cultures resulting from a week's growth of the clusters all contained normal cells, together with triradiates and many more ovals than 
were in the original clusters. In three tests the normals were $35 \mu$ long within the week, in the other four they did not exceed $25 \mu$ after 3 weeks. In several of these tests many very small triradiates in process of development from ovals, as described below, were observed.

The second group of experiments concerns oval cells which had been isolated from clone normal cultures. In five experiments, in November 1940 (Table I, Series ' $N$ '), small clusters of three or four oval cells each were placed in freshly sterilized media. It was known definitely that no armed cell was present. Within 3 weeks one of these experimental cultures had given rise to many more ovals and to normal cells $30 \mu$ long. The other four cultures produced at first ovals only through several stages of subculturing. One of them became heavily infected by bacteria and was thrown away, whilst one other was lost by enemy action in March I94I. The two remaining cultures contained only oval cells until the end of the following May when some of the ovals began to elongate to form normals. By the end of July these normals were mainly $20-25 \mu$ long. No triradiate had as yet been seen amongst them, but a month later a few three-cornered oval cells and a few small triradiates were observed. In later subcultures occasional triradiates were seen, but were very rare until the autumn of 1942 when some increase in the abundance of this type occurred.

Prior to the five experiments just recorded four less precise tests had been made in May 1940. Small clusters of ovals from a clone normal culture had been separated into small flasks. Each cluster contained some armed cells as well. In a week there were to be seen transition stages between oval and normal cells; there had also been a great increase in the numbers of ovals and normals present. These cultures were kept for 4 weeks and then discarded; during that time no triradiate cell was seen although a special search was made for them.

From all the experiments it is clear that oval cells, however derived, multiply by binary fission and sooner or later develop arms. These are generally only two in number, the resulting frustule being normal in shape. There is generally no special tendency for oval cells derived from triradiates to grow three arms, and thus a triradiate culture will in course of time come to contain normal cells. Much less frequently do some ovals develop three arms to become triradiate, but only a very small proportion usually does so, whether the ovals be derived originally from triradiate or from oval cells. In my experience Series ' $U$ ' was exceptional in producing almost as many triradiates direct from ovals as normal cells from ovals. At present it is not possible to suggest any special condition or set of conditions which might be regarded as a predisposing or causative factor, or factors, in inducing the development of more than two arms. Always when triradiates have arisen from ovals many more normal cells have been produced in the same culture at the same time. Neither is it known why sometimes there is a long period between isolation of ovals and their subsequent development of arms-the ovals in the meanwhile multiplying abundantly-whilst at other times fully developed normals appear 
almost immediately. The type of culture medium used does not seem to have an influence on this. It may, however, be significant that long delay has in the main been associated with the short dull days of winter, whilst rapid outgrowth of arms has generally, but not invariably, taken place in the spring and summer. Daily duration and intensity of light, and perhaps temperature, may thus be suspected of some influence in this respect. To test this some simple experiments were made but the results were inconclusive. Rigid control of temperature, intensity of light and duration of lighting will be necessary before these physical factors can be ruled out as ineffective.

The enlargement of the oval cell to the full-sized armed form does not involve auxospore formation. In all the cultures I have examined and of all the innumerable cells I have seen there has been nothing that in any way
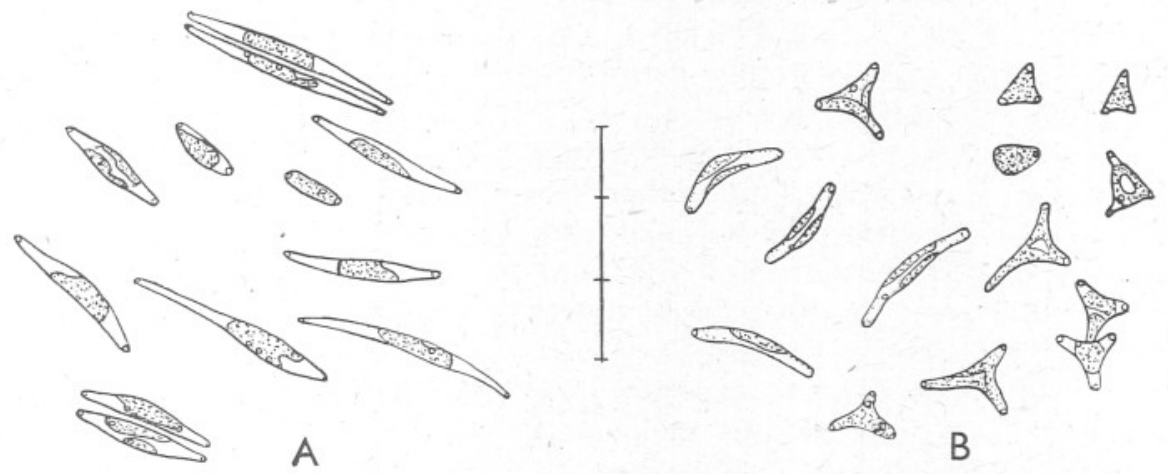

Fig. 4. A. Stages in the production of normal cells by elongation from ovals which had themselves originated in a clone normal culture (Series II). Two division stages at differing lengths are shown. B. Cells developed from ovals which had been removed from a clone triradiate culture (Series III). In addition to cells elongating to form normals there were many three-cornered ovals and small triradiates formed from them. Some of the small triradiates were dividing and a division stage is included in the lower right-hand corner of the figure. Each division of the scale represents $10 \mu$.

resembled an auxospore. The arms merely grow out from the oval at each end - in other words the oval elongates-or from three corners if a triradiate is being formed. They appear to grow out steadily and not in sudden jumps. In a culture in which cells are actively elongating (Fig. 4A) all sizes are to be seen between oval cells and fully, or nearly fully formed cells with long arms. Fission stages at any size are common (Fig. 4 A, B); it thus appears that as elongation proceeds division takes place regularly whatever the length reached.

The oval cell is tightly packed with the chromatophores; often at each end a refringent globule is to be seen, as already described. As elongation begins a space forms at each end between the chromatophores and the cell wall. When globules are present they usually remain close beside the chromatophores, but at the apical ends of the cells there is often an appearance as of polar nodules. As a rule elongation through the transition stages is fairly 
rapid, although it may take several days. The final length reached is very variable; it has already been recorded how in some cultures $30-35 \mu$ was reached by a large number of cells in a week or so, whilst in other cultures it took longer to reach even $25 \mu$. Cultures in which the maximum cell length reached during the first relatively rapid lengthening is $25 \mu$ or thereabouts generally show a slow increase in maximum length from subculture to subculture during succeeding months. This process will be discussed in the next section.

This growth in length of the cells is quite unlike that normally associated with diatom frustules where strong silicification of the cell wall is generally held to preclude size increase which is brought about, when needed, by auxospore formation. In the Nitzschia of these cultures silicification is at best extremely weak, the cell wall dissolving entirely in acids, quickly so when the acid is used hot. Incineration on a cover-glass after washing away the salt water by fresh will, if carefully performed, yield fairly clean valves, but even by this method the cell wall is destroyed almost as soon as the softer contents. The valves, moreover, are quite pliable and can be bent without fracturing. It may be that what silicification there is is mainly confined to the valves and that the thinner girdle pieces are even less strongly armoured. Under these circumstances there can be little hindrance to growth of the cell wall, and this may well account for what would otherwise in a diatom be regarded as a remarkable method of growth.

It should be noted that a number of species of diatoms have been reported as having lost their siliceous skeletons in culture, this being followed by variability in cell shape. Wiedling (I94I) discusses some of these observations and reports on one of his own on N. Kützingiana var. exilis Grun., where the skeleton disappeared after the normal form had been cultivated for many years. However, none of these instances appears exactly comparable with the Nitzschia of the Plymouth cultures in which light silicification seems to be the normal condition. Specimens of the same species from the hatching tank at Charsaig (see p. 265) dissolved in hot mineral acids to leave no trace as do the culture ones, though perhaps a little less readily. These naturally occurring specimens were thus very lightly silicified, and there is therefore no adequate reason to suppose that long years of culturing are primarily responsible for the light silicification of cultured cells. A species of Nitzschia-which is possibly N. closterium (Ehr.) W. Sm. and which is discussed below (p. 263)-common in dredgings and in aquarium tanks likewise readily dissolves in acids which leave intact the valves of other diatoms treated with them at the same time.

It is probable that the usual conception of size decrease with successive division does not hold for all diatoms, and that when silicification is weak, or where special structural features permit-as in Eunotia pectinalis var. minor, where the curvature of the girdle allows new valves to be formed as big as the parent ones (Geitler, 1932)-multiplication may take place with constant apical length, or even with increase in length, though such instances are likely to 
be rare, the Nitzschia of the Plymouth cultures being one of these. Recently Wiedling (1943) has briefly discussed the general problem of size variation in diatoms, mentioning his own observations on various species of Nitzschia, particularly N. subtilis var. paleacea Grun., N. Kützingiana Hilse and N. palea var. debilis (Kg.) Grun., where growth with constant apical length was sometimes observed.

\section{Variation IN LENGTH of THE Normal Cell}

In these studies the maximum cell length is used as a standard of measurement. Since cultures contain all sizes down to ovals the determination of the average cell length would have been preferable; the time and eyestrain necessary to make sufficient measurements would, however, have been out of all proportion to the value of the results obtained. It was found that the maximum length was fairly quickly determined, for it was only necessary to measure a number of the longest cells seen, and the figure obtained did give a fair indication of the cell size of the culture. The maximum length is usually shown by only a small percentage of the cells present, but a big proportion are generally just a few microns shorter. Very occasionally an exceptional cell considerably longer than the common maximum would be encountered, but they were so rare that they have been ignored for present purposes. There are nearly always a number of cells of all lengths between that of the maximum and that of the ovals, but ones much shorter than the maximum were in general in small proportion.

There does not appear to be any great variation in maximum cell length during the growth of a subculture from the time when it is first inoculated until growth ceases. This has been checked from time to time during the growth of typical subcultures. There has, however, been noted a slight increase in maximum length during the growth of a subculture belonging to a series in which the maximum was steadily increasing. The increase from subculture to subculture is generally of the order of $\mathrm{I} \mu$ when measurements are made at equivalent growth stages; similarly with any decrease that takes place. More rapid changes occur from time to time. Tables I and II record changes in maximum length in those cultures for which records have been kept; all of them began as a few isolated ovals, except that with the 'A' series a few triradiates, but no normals, were present as well. It will be noted that the records for the ' $A$ ' series cover a period of 3 years during which there were twentytwo subcultures, whilst for the ' $\mathrm{T}$ ' and ' $\mathrm{N}$ ' series the records cover $2 \frac{1}{2}$ years and they were subcultured fifteen times. The ' $A$ ' series was always grown in a I 1. flask, the ' $T$ ' and ' $N$ ' series in wide-necked flasks holding about I 20 c.c. Both types were only half-filled with culture medium, as is the usual practice. In the smaller flasks growth came more or less to a standstill-owing to exhaustion of nutrients -2 or 3 weeks before subculturing; all the flasks, large and small, were subcultured together. The large flasks were always subcultured shortly before or after attaining maximum density. Cells were measured, alive or after preservation in formalin, a little while before this 


\section{Table I. Variation in Maximum Length of Normal Cells in Cultures grown from Oval Cells}

\begin{tabular}{|c|c|c|c|c|c|c|c|c|c|c|c|c|}
\hline \multirow[b]{2}{*}{ Date } & \multirow[b]{2}{*}{$\begin{array}{c}\text { Sub- } \\
\text { cultures } \\
\text { nos. }\end{array}$} & \multicolumn{6}{|c|}{ 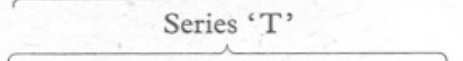 } & \multicolumn{5}{|c|}{ 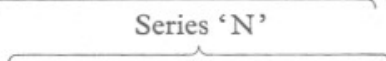 } \\
\hline & & I & II & III & IV & V & $\mathrm{VI}$ & I & II & III & IV & V \\
\hline I9. xi. 40 & I & Oval & Oval & Oval & Oval & Oval & Oval & Oval & Oval & Oval & Oval & Oval \\
\hline 3. xii. 40 & I & , & y' & , & 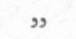 & " & & - & , & , & " & " \\
\hline I0. xii. 40 & I and 2 & פ & , & , & , & , & , & - & , & , . & , & $30 \mu$ \\
\hline I6. xii. 40 & I and 2 & , & , & , & , & , & , & - & , - - - & , & , & $30 \mu$ \\
\hline 8. i. $4 \mathrm{I}$ & $I$ and 2 & פ & , & פ - - la & פ, & , & , & - & " & , & , & , \\
\hline 4. ii. $4 \mathrm{I}$ & 2 & , & " & , & , & $\mathscr{8}$ & , & - & " & M & " & , \\
\hline 26. v. $4 \mathrm{I}$ & 3 & - & - & , & 一 & I8 $\mu$ & , & - & $20 \mu$ & I5 $\mu$ & - & - \\
\hline 23. vii. 4I & 4 & - & - & $24 \mu$ & - & $27 \mu$ & $20 \mu$ & - & $22 \mu$ & $25 \mu$ & - & - \\
\hline 25.viii. 4 I & 5 & - & - & $29 \mu$ & - & $30 \mu$ & $24 \mu$ & - & $25 \mu$ & $27 \mu$ & 一 & - \\
\hline II. ix. 4I & 6 & - & - & $26 \mu$ & - & $26 \mu$ & $\overline{-}$ & - & $27 \mu$ & $27 \mu$ & $\overline{-}$ & 一 \\
\hline Io. xi. $4 \mathrm{I}$ & 7 & - & - & $26 \mu$ & - & $26 \mu$ & $26 \mu$ & - & $25 \mu$ & $25 \mu$ & - & - \\
\hline 2. i. 42 & 8 & - & - & $27 \mu$ & - & $28 \mu$ & $26 \mu$ & - & $28 \mu$ & $28 \mu$ & - & - \\
\hline IO. iii. 42 & 9 & - & - & $27 \mu$ & - & $26 \mu$ & $27 \mu$ & - & $27 \mu$ & $28 \mu$ & - & - \\
\hline 20. V. 42 & IO & - & - & $28 \mu$ & - & $28 \mu$ & $29 \mu$ & - & $28 \mu$ & $29 \mu$ & - & - \\
\hline 30. vi. 42 & II & - & - & $29 \mu$ & - & $30 \mu$ & $27 \mu$ & - & $27 \mu$ & $29 \mu$ & 一 & - \\
\hline I I. viii. 42 & I2 & - & - & $28 \mu$ & - & $30 \mu$ & $26 \mu$ & - & $29 \mu$ & $30 \mu$ & - & - \\
\hline II. ix. 42 & I3 & - & - & $29 \mu$ & - & $3 \mathrm{I} \mu$ & $26 \mu$ & - & $29 \mu$ & 3 I $\mu$ & - & - \\
\hline 20. i. 43 & I4 & - & - & $29 \mu$ & - & $32 \mu$ & $25 \mu$ & - & $26 \mu$ & $3 \mathrm{I} \mu$ & - & - \\
\hline 20. ii. 43 & I5 & -- & - & $29 \mu$ & - & $29 \mu$ & $25 \mu$ & - & $26 \mu$ & $30 \mu$ & - & 一 \\
\hline 22. iii. 43 & I6 & - & - & $30 \mu$ & - & $30 \mu$ & $26 \mu$ & - & $26 \mu$ & $29 \mu$ & - & - \\
\hline 3. vi. 43 & I7 & 一 & - & $29 \mu$ & - & $29 \mu$ & $25 \mu$ & - & $25 \mu$ & $29 \mu$ & 一 & - \\
\hline
\end{tabular}

density was reached, and the figures are mainly for cultures at the end of their growth. Occasionally, as already mentioned, cells were measured during earlier growth stages as a check on results.

It will be seen from the figures that there is a definite, usually slow, change in maximum length over a period of several months. The general cell size of the cultures reflected these changes, those with a high maximum containing a large proportion of long cells, the reverse, of course, being true for those with a low maximum. The differences were sufficiently distinct to be readily noticeable, to an experienced eye, without actual measurement. There is no correlation with the seasons, and size may increase in one series whilst decreasing in another. All the flasks stood side by side and there could have been little difference between one and another.

The figures given for the ' $\mathrm{A}$ ' series, which covers the longest period, are the most interesting. The normal cells in the culture originated from ovals which were- removed with a few triradiates from Series III in May 1940. It will be seen that an initial rapid increase in maximum length was followed by a slower increase until February I94I when cells $32 \mu$ long were measured. In that month normal cells $29 \mu$ long were common and the smallest seen, apart from some ovals, were about $26 \mu$ long. This subculture, No. 'A' 9, was lost by enemy action, and the series was restarted by subculturing again from the old ' $A$ ' 8 subculture which partially survived in the shattered remains 


\section{Table II. Variation in Maximum Length of Normal Cells in} Cultures grown From Oval Cells

\begin{tabular}{|c|c|c|c|c|c|c|c|}
\hline \multirow[b]{2}{*}{ Date } & \multicolumn{2}{|c|}{ Series 'A' } & \multicolumn{2}{|c|}{ Series 'U' } & & \multicolumn{2}{|c|}{ Series 'A' (cont.) } \\
\hline & $\begin{array}{l}\text { Sub- } \\
\text { culture } \\
\text { no. }\end{array}$ & $\underset{\text { length }}{\text { Maximum }}$ & $\begin{array}{l}\text { Sub- } \\
\text { culture } \\
\text { no. }\end{array}$ & $\begin{array}{c}\text { Maximum } \\
\text { length }\end{array}$ & Date & $\begin{array}{l}\text { Sub- } \\
\text { culture } \\
\text { no. }\end{array}$ & $\underset{\text { length }}{\text { Maximum }}$ \\
\hline 8. v. 40 & I & Oval & - & - & 26. v. $4 \mathrm{I}$ & $9 a$ & $28 \mu$ \\
\hline I3. v. 40 & I & & - & - & 23. vii. $4 \mathrm{I}$ & I0 & $26 \mu$ \\
\hline I7. v. 40 & I & $16 \mu$ & - & - & 25 . viii $4 \mathrm{I}$ & II & $2 \mathrm{I} \mu$ \\
\hline 27. v. 40 & 2 & $2 \mathrm{I} \mu$ & 一 & - & I5. ix. $4 \mathrm{I}$ & I 2 & $2 \mathrm{I} \mu$ \\
\hline I3. vi. 40 & 3 & $25 \mu$ & - & - & 4. xi. 4I & 13 & $23 \mu$ \\
\hline 24. vi. 40 & 4 & $27 \mu$ & - & - & 2. i. 42 & 14 & $24 \mu$ \\
\hline Io. vii. 40 & - & - & I & Oval & 7. iv. 42 & I5 & $26 \mu$ \\
\hline I9. vii. 40 & - & - & I & , & 20. v. 42 & 16 & $27 \mu$ \\
\hline 24. vii. 40 & 5 & $29 \mu$ & I & I5 $\mu$ & 30. vi. 42 & I7 & $29 \mu$ \\
\hline 3 I. vii. 40 & & & I & $23 \mu$ & II.viii. 42 & I8 & $29 \mu$ \\
\hline 9.viii. 40 & 6 & $29 \mu$ & - & - & II. ix. 42 & I9 & $28 \mu$ \\
\hline 20. viii. 40 & - & - & 2 & $25 \mu$ 。 & 20. i. 43 & 20 & $27 \mu$ \\
\hline 28.viii. 40 & 7 & $30 \mu$ & - & & 20. ii. 43 & $2 \mathrm{I}$ & $25 \mu$ \\
\hline II. ix. 40 & 7 & $30 \mu$ & 2 & $26 \mu$ & 22. iii. 43 & 22 & $25 \mu$ \\
\hline I3. xi. 40 & 8 & $30 \mu$ & 3 & $27 \mu$ & 3. vi. 43 & 23 & $28 \mu$ \\
\hline 4. ii. $4 \mathrm{I}$ & 9 & $32 \mu$ & 4 & $28 \mu$ & & & \\
\hline
\end{tabular}

of its flask. The new subculture, 'A' $9 a$, showed a decrease in size, and this decrease continued until by August and September I94I only short cells, most of them less than $20 \mu$ long, were present. There followed a slow lengthening for nearly a year, followed by a slight shortening, with the last measurement in June I943 showing again an increase in maximum size. Similar changes in length have been observed in the clone normal cultures, Series I and II and in other stock cultures, but the data for these are not so complete and are therefore not given.

The interpretation of the ' $A$ ' series is complicated by the presence throughout of a considerable proportion of triradiates which at certain times, as will be shown later, gave rise to some normals by a process of losing one arm. However, as normals so produced appear always to be small, shorter than about $25 \mu$, their production probably does not affect the picture to any "appreciable extent. This complication does not arise in the ' $T$ ' and ' $N$ ' series where triradiates were always rare and where similar fluctuations in length of the normal cells were observed.

In diatoms a decrease in the general cell size through successive divisions is followed as a rule by a sudden increase brought about by auxospore formation. In these Nitzschia cultures auxospores have never been seen, and when an increase in maximum cell length takes place it is always slower and more gradual than would be likely if normal auxospores were produced. It seems probable that the cells, being so lightly silicified, merely grow in length in the ordinary manner of a plant cell, material being added to the cell wall as required. Perhaps slow shrinkage can also take place by absorption.

When a Nitzschia cell divides, one of the daughter cells always looks to be slightly shorter than the other, as is usual for a diatom. Once they have 
separated, however, there seems to be no reason why the shorter should not enlarge slightly; if this should happen the general cell size of a culture would be maintained, or even raised. Auxospores would thus not be needed by this species and it may well be they are never formed.

Allen \& Nelson (I9IO, p. 462) noticed no appreciable diminution in size in their cultures over a period of 2 years, although the total growth observed was enormous. Unfortunately, they do not appear to have made any measurements or they might possibly have found some slight changes. They also do not appear to have noticed any variation in the size of the cells in any one culture, as has been a common feature in my cultures, the direct descendants of theirs. My findings are in agreement with their conclusion that 'the theory of gradual decrease in size with successive generations cannot be generally applied'.

The triradiate does not readily lend itself to measurement, but there is little doubt that it undergoes similar size changes. Cultures with predominantly large triradiates and others with mainly small ones have frequently been noticed.

\section{The Formation and Behaviour of Triradiate Cells in Culture}

It has been shown how triradiate cells may arise in cultures of the normal form by the development of three-cornered ovals. It is not known how an oval cell becomes three-cornered, but it is definite that such cells are infrequent. It follows that in any pure culture of normals triradiates are likely to put in an appearance sooner or later. For long periods, as in the ' $\mathrm{T}$ ' and ' $\mathrm{N}$ ' series of my experiments, and presumably also in the Plymouth stock cultures whilst under the care of Dr Allen, these triradiate cells may be present in very small numbers only to be found by special searching. If there be any physical and chemical conditions favouring their appearance these are still to be discovered; some preliminary experiments on growing cultures of pure normal cells under varying light intensity gave only negative results. It should be noted that triradiates first appeared in Series I and II (clone normal) whilst they were being kept at a constant temperature of $\mathrm{I} 2^{\circ} \mathrm{C}$., as they had been since they were first formed. It was not until after enemy damage to the controlled temperature chambers in March I94I that these cultures were subject to the temperature changes of an ordinary room. There is also no evidence whatever that exhaustion of nutrients, or the presence of moulds or bacteria, has any effect in bringing about triradiate production. In old infected pure normal cultures many misshapen cells may be found, especially in the thick mass at the bottom of the flask, but these are multitudinous in form, and though some of them have three or more bent and uneven arms no regular triradiate has been seen amongst them. Subcultures made from such masses have never yielded triradiate cells; they have given rise to normals only. There is thus no reason to suspect that the presence of triradiates is an indication of bad cultural conditions. 
There has been little to suggest that normal cells ever become triradiate by growing out a third arm, although the opposite process of a triradiate becoming normal by gradually eliminating one arm is of common occurrence. Nevertheless, a very few normals, two or three out of many hundreds of thousands of normals seen during the last few years, have had one arm bifid in a manner suggesting that the process is not impossible and that it may occasionally take place. However, there is no doubt that as a general rule triradiates arise from normals only through the intermediary of oval cells.

The notable increase in recent years of the numbers of triradiates in the Plymouth stock cultures and in cultures elsewhere (see p. 238) cannot yet be fully explained. It might be that from time to time strains of triradiates arise which have a higher division rate than that of the normal cells in the same culture. The result of mixing cells from the clone triradiate with cells from a clone normal was therefore likely to be interesting, and accordingly the following experiment was carried out.

In June I94I triradiates from Series III and normals from Series II were mixed in about equal proportions, about 5 c.c. of a well-grown subculture of each being used. The mixture was estimated-by counting a thousand cellsto be $5 \mathrm{I} \cdot 5 \%$ triradiate. Two I 1 . flasks containing Allen-Miquel sea water were inoculated from this mixture; these were designated Series IVA and Series IVB. From then on they were regularly subcultured, and from time to time estimations were made of the percentage triradiate; these results are recorded in Table III. For each estimation at least five hundred cells were counted, nearly always several hundreds more. In the earlier estimations usually between a thousand and fifteen hundred cells were counted. The sampling error of the percentages given is of the order of $\mathrm{r} \cdot \mathrm{O}$. It will be seen that the proportion of triradiates present increased in both series by some $20 \%$ during the first month and thereafter rose steadily though more slowly, until by February 1944 over $90 \%$ of both series consisted of triradiates.

In April I942 two additional series of cultures were begun in order to test the effect of changing the medium. Similar sized flasks containing Erdschreiber were inoculated from Series IVA and IVB and subcultures were continued in this medium. The figures (Tables III) show that in Series IVA there was a preliminary slight fall in the percentage triradiate, followed by a steady rise some months later. In Series IVB there was merely a check, followed by an almost steady rise, although as in Series IV A the percentage triradiate never quite catches up with that in the Allen-Miquel sea water. The Erdschreiber thus appears in these cultures to be slightly more favourable to the normal cells, mainly perhaps owing to the initial fall or check in the numbers of triradiate when the change-over from the other medium took place. In any event the effect is slight. It has already been remarked (p. 242) that there is often a tendency for oval cells to be produced more readily in Erdschreiber than in Allen-Miquel, and this tendency has sometimes been noticeable in these Series IV cultures. As ovals develop more often into normals than into 
Table III. Variation in the Percentage Triradiate of Mixed Clone Cúltures of Triradiate and Normal Cells and the Percentage of THE TRIRADIaTeS With SHORTENED ARMS

\begin{tabular}{|c|c|c|c|c|c|c|c|c|c|c|c|}
\hline \multirow{3}{*}{$\begin{array}{l}\text { Sub- } \\
\text { cultures } \\
\text { made }\end{array}$} & \multirow[b]{3}{*}{$\begin{array}{l}\text { Date } \\
\text { counted }\end{array}$} & \multicolumn{4}{|c|}{ Series IVA } & \multicolumn{4}{|c|}{ Series IVB } & \multirow{2}{*}{\multicolumn{2}{|c|}{$\begin{array}{l}\text { Series IVC } \\
\text { Allen-Miquel }\end{array}$}} \\
\hline & & \multicolumn{2}{|c|}{ Allen-Miquel } & \multicolumn{2}{|c|}{ Erdschreiber } & \multicolumn{2}{|c|}{$\overbrace{\text { Allen-Miquel }}$} & \multicolumn{2}{|c|}{ Erdschreiber } & & \\
\hline & & $\begin{array}{l}\text { Tri- } \\
\text { radiate }\end{array}$ & $\begin{array}{l}\text { Short- } \\
\text { armed }\end{array}$ & $\begin{array}{l}\text { Tri- } \\
\text { radiate }\end{array}$ & $\begin{array}{l}\text { Short- } \\
\text { armed }\end{array}$ & $\begin{array}{c}\text { Tri- } \\
\text { radiate }\end{array}$ & $\begin{array}{l}\text { Short- } \\
\text { armed }\end{array}$ & $\begin{array}{c}\text { Tri- } \\
\text { radiate }\end{array}$ & $\begin{array}{l}\text { Short- } \\
\text { armed }\end{array}$ & $\begin{array}{l}\text { Tri- } \\
\text { radiate }\end{array}$ & $\begin{array}{l}\text { Short- } \\
\text { armed }\end{array}$ \\
\hline I3. vi. 4I & I3. vi. $4 \mathrm{I}$ & $51 \cdot 5$ & - & - & - & $5 \mathrm{r} \cdot 5$ & - & - & - & - & - \\
\hline I3. vi. $4 \mathrm{I}$ & Ir. vii. 4I & & - & - & & $73 \cdot 6$ & - & & & & \\
\hline 24. vii. 4I & 24. vii. $4 \mathrm{I}$ & - & - & - & - & & - & - & - & $7 \cdot 0$ & \\
\hline I9. vii. 4I & 20.viii. $4 \mathrm{I}$ & $74 \cdot 7$ & - & - & 一 & $76 \cdot \mathrm{I}$ & - & - & - & & \\
\hline 24. vii. 4I & 20.viii. 4I & & - & - & - & - & - & - & - & ro.3 & \\
\hline 28.viii. $4 \mathrm{I}$ & 27. ix. 4I & $74 \cdot 0$ & - & - & - & $77 \cdot 0$ & - & - & - & 10.5 & \\
\hline 8. x. 4I & 4. xi. $4 \mathrm{I}$ & $73 \cdot 2$ & 8.0 & - & & $77 \cdot 4$ & - & - & - & $12 \cdot 6$ & - \\
\hline 26. xi. 4I & 9. i. 42 & $77 \cdot 0$ & 一 & - & - & $79 \cdot \mathrm{I}$ & - & - & - & I $7 \cdot 3$ & - \\
\hline 4. ii. 42 & I. iv. 42 & $78 \cdot 0$ & - & - & 一 & $8 \mathrm{I} \cdot \mathrm{I}$ & - & - & - & $20 \cdot 4$ & \\
\hline I6. iv. 42 & 7. v. 42 & $8 \mathrm{r} \cdot 5$ & $2 \cdot 3$ & $75 \cdot 8$ & $2 \cdot 9$ & 82.4 & $I \cdot I$ & $8 \mathrm{I} \cdot 2$ & $\mathrm{I} \cdot 2$ & - & - \\
\hline 29. v.: 42 & 30. vi. 42 & & & & - & 847 & $\mathrm{I} \cdot 7$ & $85 \cdot 6$ & $2 \cdot 9$ & - & \\
\hline 2. vii. 42 & I8.viii. 42 & $82 \cdot 8$ & $2 \cdot I$ & $75^{\circ} 0$ & $2 \cdot 6$ & & $I \cdot 6$ & $86 \cdot 8$ & 3.5 & $4 \mathrm{I} \cdot 2$ & .0 .0 \\
\hline 26.viii. 42 & 2. $x .42$ & $83 \cdot 8$ & $I \cdot I$ & $74 \cdot 9$ & $4 \cdot 8$ & 89.5 & $\mathrm{I} \cdot 4$ & $86 \cdot 3$ & $6 \cdot 4$ & $42 \cdot 8$ & $2 \cdot 5$ \\
\hline I4. x. 42 & 25. xi. 42 & $82 \cdot 2$ & I.9 & $68 \cdot 4$ & $4 \cdot I$ & $89 \cdot I$ & $\mathrm{r} \cdot 9$ & $78 \cdot 7$ & 3.8 & $48 \cdot 2$ & 0.9 \\
\hline 2I. xii. 42 & 20. ii. 43 & $7 \cdot 9$ & 0.1 & $72 \cdot 9$ & $\mathrm{I} \cdot 9$ & $90 \cdot 4$ & 0.6 & 84.9 & $2 \cdot 5$ & 54.4 & 0.7 \\
\hline 24. ii. 43 & 3I. iii. 43 & $88 \cdot 8$ & 0.2 & $77 \cdot 5$ & $\mathrm{I} \cdot 6$ & $9 \mathrm{I} \cdot 7$ & 0.6 & $83 \cdot 8$ & $I \cdot O$ & 557 & I. 4 \\
\hline 21. iv. 43 & 3. vi. 43 & $9 I \cdot 3$ & 0.5 & $77 \cdot 9$ & $2 \cdot I$ & $92 \cdot 3$ & $I \cdot 5$ & $86 \cdot 4$ & I. 4 & $6 \mathrm{I} \cdot 3$ & I.7 \\
\hline 7. vi. 43 & I5. vii. 43 & $9 \mathrm{I} \cdot 6$ & 0.3 & 85.0 & 0.7 & $9 \mathrm{I} \cdot 7$ & $4 \cdot 3$ & $88 \cdot 5$ & $I \cdot 9$ & $68 \cdot 7$ & $2 \cdot 7$ \\
\hline 6.viii. 43 & I7. ix. 43 & $92 \cdot 0$ & $2 \cdot 3$ & $88 \cdot 7$ & $3 \cdot 6$ & 93.0 & $4 \cdot 8$ & 88.0 & $4 \cdot 2$ & 80.4 & $5 \cdot 3$ \\
\hline 6. x.: 43 & I5. xi. 43 & $92 \cdot 6$ & $\mathrm{I} \cdot 4$ & $90 \cdot 3$ & 3.8 & 90.9 & $3 \cdot 5$ & $90 \cdot 2$ & $4 \cdot I$ & $8 \mathrm{I} \cdot \mathrm{I}$ & $6 \cdot 4$ \\
\hline I7. xii. 43 & I9. ii. 44 & $95 \cdot 3$ & 0.8 & $9 \mathrm{I} \cdot 9$ & $2 \cdot 2$ & $92 \cdot 8$ & $2 \cdot I$ & $90 \cdot 8$ & $2 \cdot I$ & - & \\
\hline
\end{tabular}

triradiates, those cultures producing most ovals are likely to have a higher percentage of normals, other things being equal.

More striking even than in the Series IVA and IVB cultures is the great increase in abundance of triradiates in another mixed culture where the initial percentage triradiate was much less. This series, IVC, was begun in July I94I with a mixture of Series II with Series III in such proportions that the mixture was $7 \%$ triradiate. Table III shows that from the first there was a steady increase in the proportion triradiate, until by November 1943 over $80 \%$ of the culture consisted of these cells.

In these experiments the triradiates evidently grew more strongly, that is, had a higher division rate, than the normal cells mixed with them. It has already been suggested (p. 25I) that this is what had happened in the Plymouth and other stock cultures during the years when the triradiate type of cell seemed to be ousting the normal. This phenomenon can thus be explained on the assumption that from time to time in cultures of the normal cell there are produced ovals from which arise more vigorously growing triradiates. It may well be that some strains have more vigour and a higher division rate than others, and that it is only when a vigorous strain appears that any great increase in the number of triradiates is to be noticed. Thus a number of cultures derived from Plymouth stocks some years ago and kept apart by other workers 
(e.g. the cultures kept at the Plymouth Technical College by Miss F. A. Stanbury, who obtained her material from Dr Allen in 1929) have produced few or no triradiates. Something similar appears to have happened in my own ' $T$ ' and ' $N$ ' experiments in which triradiates were very rarely seen for 4 years, after which they suddenly became very common in four out of the five series of subcultures. In the fifth they were less numerous. The early subcultures kept at the Royal College of Science (see p. 238) which produced such an abundance of triradiates not long after separation from the early Plymouth stocks may have produced a particularly vigorous and fast-growing strain of triradiate shortly after the separation had taken place. It may also be that a strain will weaken in vitality after a period of years.

\section{Short-ARMed Triradiates and the Production of NoRMAL CELlS FROM THEM}

In most cultures containing triradiates a number of the latter are usually to be found with one arm considerably shorter than the other two (Fig. 5B) or with one long and two short arms when the cell has a Y-shaped appearance. In some
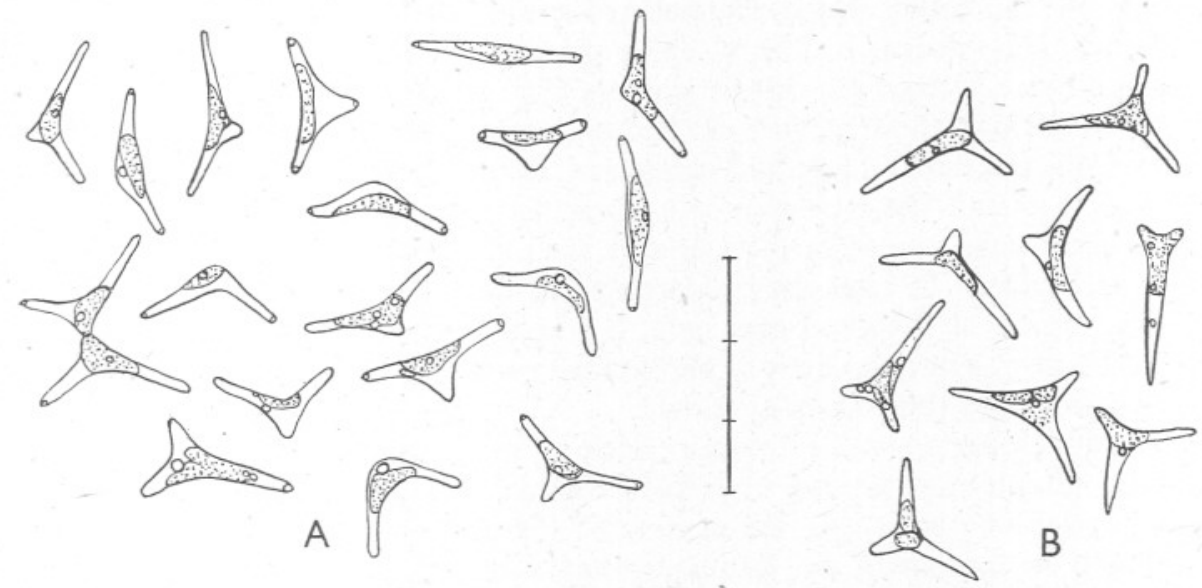

Fig. 5. A. Short-armed triradiates and normals produced from them. All were drawn from Series III on Io December I94I from the subculture of 8 October I94I (see Table IV). B. Various types of short-armed triradiates from different cultures. Each division of the scale represents Iо $\mu$.

cultures, as in the clone triradiate during the first 3 months of its growth, such cells are absent or are very rare; at other times they may be common, and all degrees of shortening are to be observed from scarcely at all to the shortest arm being nothing more than a slight swelling on the other two (Figs. 5 A, 6c). The question arises whether these forms are abnormalities or whether they are stages in the conversion of triradiates into normals. It has already been mentioned (p. 25I) that there is no definite evidence of the converse 
process taking place, although with such a variable species it cannot be maintained that it would never happen.

These short-armed triradiates first came prominently to notice in the autumn of 194I. It was in the summer of that year that the regular stock cultures, numbered respectively 569 and 589 , had become almost entirely triradiate and the clone Series III was still almost pure triradiate. During the following autumn all three series of cultures produced a great number of normal cells, thereby completely altering their composition and general appearance. At this time very large numbers of short-armed triradiates, of all degrees of shortening (Fig. 5A), were to be seen in the cultures, and there can be no doubt whatever that these had been derived from ordinary triradiate cells. Far too few normals had been in the cultures previously for there to be any possibility that the shortarmed triradiates were normals in process of acquiring third arms. There can likewise be little hesitation in accepting the interpretation that these triradiates were converting to normal by a process of gradually shortening one arm until it was finally eliminated. Large numbers of normals had appeared, and there was no special reason to suspect at this time that they had been derived directly by the development of oval cells. The latter were no more frequent than usual, whilst short-armed triradiates were relatively abundant.

Whilst this process had been taking place in the Plymouth cultures similar changes were going on in cultures kept at Hull by Dr C. E. Lucas. For several years previously the Hull cultures had undergone changes closely parallel with the Plymouth ones. They had originated from Plymouth stock sent to Hull about 1930 and have been grown there independently ever since. A few triradiates were noticed in 1932, and by 1934 they may have formed about I \% of the cultures. In 1936 the proportion had risen above $50 \%$, reaching $97 \%$ by the spring of 1939 and over $99 \%$ by the summer of I94I. In addition to these cultures a sample of my clone triradiate was sent to Hull in February 1940 and maintained there since that date.

In November 194I, Dr Lucas noticed in all his cultures a sudden increase in the numbers of normal cells present. At that time he was unaware of happenings at Plymouth. He made a rough analysis on I8 November, subcultured on the 29th of that morith and again on I6 January 1942, and counted both sets of subcultures early in February 1942. His results are shown in Table IV. If these figures are compared with those for the Plymouth stock cultures and clone triradiate (Series III) for the same period (Table V), it will be seen how closely they correspond, the greatest divergence being shown by

Table IV. Percentage Triradiate of Hull Cultúres

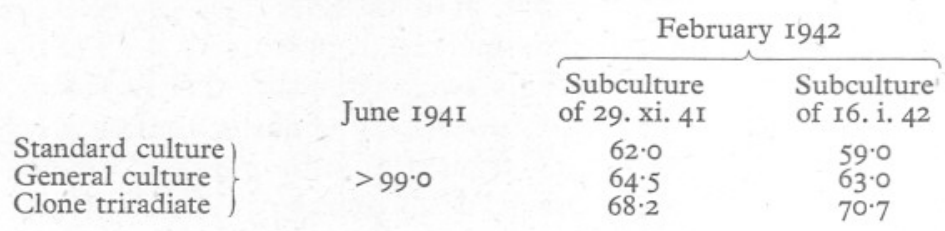


the clone triradiate culture which had most recently been divided between the two places. As at Plymouth at this time short-armed triradiates were frequent in the Hull cultures and there seems to be no doubt as to the method of change. The later history of the Hull cultures is discussed below.

In both the Plymouth and Hull cultures during the period of change (and subsequently at Plymouth whenever short-armed triradiates were common) there were normal cells which were much more curved than usual, they were indeed bent (Figs. 5A, $6 a, b$ ). It seems certain that such cells represent two arms of a triradiate after final disappearance of the third arm. In most triradiates no two arms lie along the same straight line, although this is sometimes seen. Presumably the bend ultimately straightens out; this is confirmed by finding a division stage (Fig. $6 e$ ) in which one of the daughter cells is bent and the other almost straight. Bent normals are definitely associated with short-armed triradiates, and they are not seen in cultures where the latter do not occur.

There remains the possibility that a dividing triradiate will sometimes produce a pair of daughter cells in which one will lack the third arm or be provided with only a stump of it, whilst the other is fully triradiate. Of the many thousands of division stages I have seen, none has fitted this description, but Dr Lucas tells me that he has seen one such. Thus at best this type of division must be extremely rare and the direct production of normals by this method equally rare. In the many division stages of short-armed triradiates which have been seen there

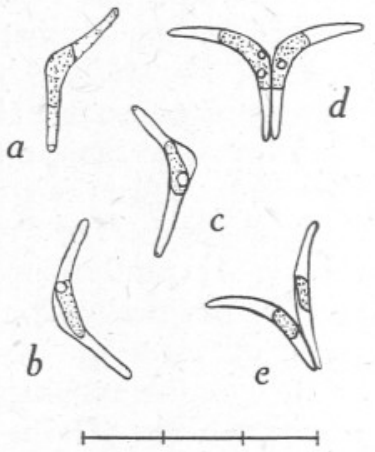

Fig. 6. $a, b, c$, types of 'bent' normals produced from triradiate cells by the loss of one arm; in $c$ the base of the third arm is still present; $d$, bent normals dividing; $e$, a division stage in which one of the daughter cells has straightened out. Each division of the scale represents Iо $\mu$. has been little difference in size or shape between the daughter cells, although one of the two does sometimes show a perceptible reduction in length of the short arm as compared with the other.

The close correspondence in behaviour of the Plymouth and Hull cultures is very puzzling. With a view to hearing whether similar events had taken place elsewhere a short account has already been published (Wilson \& Lucas, I942) calling attention to the facts. Some interesting letters were subsequently received from other workers but none had to report a similar phenomenon, though there are good indications that something of the sort happened in Edinburgh. When in 1937 Dr Gross left Plymouth for that city he took with him samples of our stock cultures. For a short period they were grown in Allen-Miquel sea water as at Plymouth, but the medium was soon changed to Erdschreiber. Dr Gross informs me that during the summer of 1940, whilst they were temporarily in charge of Dr J. E. G. Raymont, the cells were almost all triradiate, but that by February 1942 (when he kindly sent me samples) 
they were almost all normal with only a few triradiates amongst them. The change-over was not observed, but it seems likely that it took place earlier, as well as more completely, than at Plymouth. The use of Erdschreiber may have had some influence on this, but in view of the experiments described above, and the difference in subculturing practice between Hull and Plymouth where nevertheless results were so similar, one cannot regard this as furnishing a satisfactory explanation.

Since the constant-temperature apparatus was damaged by enemy bombing in March 194I the Plymouth cultures have been kept in an unheated room exposed to the ordinary daylight and temperature variations of a north window. The cultures in Hull are kept under similar conditions. It seemed possible therefore that some seasonal fluctuations might occur in the cultures, indeed, that to some extent the close correspondence between the Hull and Plymouth cultures might be related to the seasons as being a common factor for both places. The Plymouth cultures were thus watched with this end in view; it was, unfortunately, not possible to refer back to cultures earlier than I94I, as practically all preserved material was lost during the air raids of the spring of that year.

The cultures investigated were the regular Stocks 569 and 589, the clone triradiate Series III, the clone normals Series I and II, the mixed Series IVA and IVB, and the Series ' $A$ '. In every instance estimations were made of the percentage of triradiates with shortened arms, only those cells being counted in which the shortening was really definite. The amount of shortening varied from just definitely perceptible to the arm having almost entirely disappeared. The results are shown in Tables III and V alongside the percentage triradiate, which was estimated at the same time.

Over a period of 3 years it can be seen that the percentage of short-armed triradiates increases, almost without exception, in October and November of each year (in the 'A' series the maximum was in July 1942), with sometimes at the same time a corresponding fall in the percentage triradiate, or if not an actual fall often a check in the rate of increase of the percentage triradiate. In no instance, however, was the phenomenon as marked as in November 194I. The most striking figures are for the Stocks 569 and 589 and for the clone triradiate Series III, but the same trend is to be observed, though to a lesser extent, in the mixed cultures of Series IV, being more marked in the Erdschreiber cultures than in the Allen-Miquel sea water. It is well shown in the figures for the clone normal cultures Series I and II, although here the triradiates were present in very small numbers, especially at first, and the percentage figure is in each case based on only a few individuals and therefore is not so accurate. The ' $\mathrm{A}$ ' series is an exception to the general picture in that maximum shortening occurred earlier in I94I and 1942, in September and in August respectively, although in 1943 the maximum was reached in November.

From these results it seems permissible to conclude that whilst some arm reduction may take place at any time during the year there is a definite tendency 
Table V. The Percentage Triradiate of Plymouth Clone and Stock Cultures and of Series ' $A$ ' and the Percentage of the Triradiates WITH SHORTENED ARMS

Sub-
cultures
made
3. iv. 4 I
I5. vii. 4 I
28.viii. 4 I
8. x. 4 I
8. x. 4 I
27. xi. 41
I6. iv. 42
I6. iv. 42
29. v. 42
2. vii. 42
26. viii. 42
26. viii. 42
I4. x. 42
I4. x. 42
20. xii. 42
24. ii. 43
2I. iv. 43
7. vi. 43
6. viii. 43
6. x. 43
I7. xii. 43
I0. v. 45

Subcultures made

24. vii. 40

3. iv. $4 \mathrm{I}$

20. v. $4 \mathrm{I}$

I5. vii. $4 \mathrm{I}$

28. viii. $4 \mathrm{I}$

8. x. $4 \mathrm{I}$

27. xi. 4I

27. xi. 4I

I6. iv. 42

I6. iv. 42

29. v. 42

2. vii. 42

26. viii. 42

26. viii. 42

I4. x. 42

20. xii. 42

24. ii. 43

2I. iv. 43

7. vi. 43

6. viii. 43

6. x. 43

I7. xii. 43

IO. v. 45

\begin{tabular}{|c|c|c|c|c|c|c|}
\hline \multirow[b]{2}{*}{$\begin{array}{l}\text { Date } \\
\text { counted }\end{array}$} & \multicolumn{2}{|c|}{ Series III } & \multicolumn{2}{|c|}{ Stock 569} & \multicolumn{2}{|c|}{ Stock 589} \\
\hline & Triradiate & $\begin{array}{l}\text { Short- } \\
\text { armed }\end{array}$ & Triradiate & $\begin{array}{l}\text { Short- } \\
\text { armed }\end{array}$ & Triradiate & $\begin{array}{l}\text { Short- } \\
\text { armed }\end{array}$ \\
\hline 8. vi. $4 \mathrm{I}$ & $98 \cdot 8$ & - & $99 \cdot 3$ & - & 98.6 & - \\
\hline 26.viii.4I & $87 \cdot 7$ & $6 \cdot 6$ & - & - & - & - \\
\hline I5. ix. 4I & $77 \cdot 2$ & $7 \cdot 8$ & - & - & - & - \\
\hline 7. xi. 4I & $60 \cdot 0$ & $21 \cdot 8$ & $62 \cdot 6$ & $2 I \cdot I$ & $66 \cdot 4$ & $\mathrm{I} 7 \cdot 7$ \\
\hline I0. xii. 4I & 59.9 & I3. I & - & - & - & - \\
\hline I7. ii. 42 & $60 \cdot 3$ & 13.3 & $6 r \cdot 6$ & $\mathrm{II} \cdot 3$ & $64 \cdot 7$ & - \\
\hline 7. v. 42 & $62 \cdot 0$ & 6.0 & 60.9 & $6 \cdot 8$ & $66 \cdot 7$ & $5 \cdot 6$ \\
\hline 28. v. 42 & $62 \cdot 8$ & $6 \cdot 4$ & $62 \cdot 6$ & $7 \cdot 9$ & $65 \cdot 2$ & 5.5 \\
\hline 30. vi. 42 & $64 \cdot 9$ & $7 \cdot I$ & $62 \cdot 3$ & $8 \cdot 3$ & $68 \cdot 4$ & 5.9 \\
\hline 29.viii. 42 & $63 \cdot 4$ & $6 \cdot 5$ & $62 \cdot 3$ & $8 \cdot 7$ & $66 \cdot 0$ & 9.9 \\
\hline I0. ix. 42 & $64 \cdot 5$ & $8 \cdot I$ & $6 I \cdot 9$ & $9 \cdot 9$ & $65 \cdot 1$ & 10.8 \\
\hline 2. x. 42 & $64 \cdot 5$ & $10 \cdot 7$ & $62 \cdot 3$ & II 8 & $64 \cdot 9$ & 10.6 \\
\hline 25. xi. 42 & $65 \cdot 4$ & II. 4 & $59 \cdot 4$ & I $4 \cdot 3$ & $62 \cdot 0$ & II 6 \\
\hline I6. xii. 42 & $64 \cdot 0$ & $7 \cdot 7$ & 58.9 & $9 \cdot 0$ & $64 \cdot 3$ & 6.9 \\
\hline 20. ii. 43 & $67 \cdot 4$ & $2 \cdot 6$ & $64 \cdot 5$ & $3 \cdot 8$ & 67.5 & $3 \cdot 8$ \\
\hline 31. iii. 43 & $73 \cdot 6$ & $2 \cdot 7$ & $7 \mathrm{I} \cdot 2$ & $3 \cdot 3$ & $69 \cdot 6$ & $3 \cdot 7$ \\
\hline 3. vi. 43 & $67 \cdot I$ & $3 \cdot 2$ & 647 & $5 \cdot 4$ & $7 \mathrm{I} \cdot 5$ & $4 \cdot 9$ \\
\hline I5. vii. 43 & $70 \cdot 7$ & $5 \cdot 1$ & $72 \cdot 7$ & $3 \cdot 7$ & $69 \cdot 3$ & $6 \cdot 2$ \\
\hline I7. ix. 43 & $79 \cdot 2$ & 8.5 & $73 \cdot 6$ & 10.9 & 60.9 & 15.0 \\
\hline I5. xi. 43 & $75 \cdot 5$ & II $\cdot 0$ & $72 \cdot 8$ & I3. I & $58 \cdot 0$ & I5.8 \\
\hline I9. ii. 44 & $76 \cdot 8$ & $2 \cdot 5$ & 78.0 & $3 \cdot 2$ & $62 \cdot 2$ & $6 \cdot 1$ \\
\hline I3.viii. 45 & 90.5 & $I \cdot 6$ & $9 \mathrm{I} \cdot 8$ & $4 \cdot 2$ & $77 \cdot \mathrm{I}$ & $2 \cdot 6$ \\
\hline
\end{tabular}

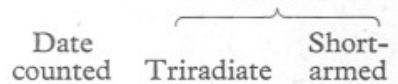

$\overbrace{\text { Short- }}^{\text {Series II }}$

Triradiate armed

Series 'A'

9. viii. 40

8. vi. $4 \mathrm{I}$

23. vii. $4 \mathrm{I}$

26.viii. 4I

I5. ix. $4 \mathrm{I}$

7. xi. $4 \mathrm{I}$

2. i. 42

I7. ii. 42

7. v. 42

28. v. 42

30. vi. 42

29. viii. 42

Io. ix. 42

2. x. 42

25. xi. 42

20. ii. 43

3I. iii. 43

3. vi. 43

I5. vii. 43

I7. ix. 43

I5. xi. 43

I9. ii. 44

I3. viii. 45 $\begin{array}{cc}\overline{0} 2 & = \\ \bar{z} & = \\ \text { very few } & =\end{array}$

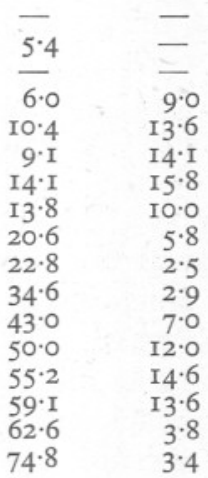

\begin{tabular}{cccc}
- & - & 46.4 & I3.6 \\
\hline-0 & - & - & - \\
- & - & 61.0 & 8.6 \\
E & - & 60.7 & II.5 \\
Extremely & - & 44.0 & 18.7
\end{tabular}

few

A few

-
-
$37 \cdot 5$
$69 \cdot 2$
$34 \cdot 0$

3.0

$3 \cdot 3$

$4 \cdot 8$
$5 \cdot 7$

$4 \cdot 9$

3.6

$5 \cdot 8$

6.7

$8 \cdot 4$

I0. 4

I $7 \cdot 6$

I 8.9

$27 \cdot 8$

$67 \cdot 7$

$34 \cdot 0$
$46 \cdot 4$

$4 \mathrm{I} \cdot 3$

25.0

$2 \mathrm{I} \cdot \mathrm{O}$

II. 4

I 4.6
20.4

20.4
24.7

I6. 6

9.9

2.0
$40.6 \quad 9.5$

$\overline{49 \cdot 5}$

II 3

Short-

$8 \cdot 6$ $8 \cdot 7$

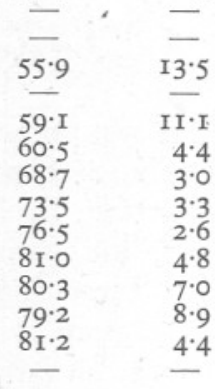


for the process to be most active during the late autumn. It is then that triradiates with mere stumps of a third arm and sharply bent normals are more frequently seen than at any other time of the year. Such stages are, on the whole, most infrequently seen in the spring.

The existence of a regular seasonal change of this nature makes it a little less difficult to understand the close correspondence between the Hull and Plymouth cultures, at least as far as time of year is concerned. It is still not clear why in I94I the change should in both places, and in so many cultures, have been of such great magnitude, and at the moment there is no rational explanation to offer.

A regular yearly cycle suggests that either light or temperature, or both, are causative factors. A few simple experiments devised to test this gave inconclusive results, perhaps because the experimental conditions were not sufficiently rigid. As regards light, duration of day seems likely to have more effect than mere variation in intensity.

\section{EXPERIMENTS WITH LOW SALINITY}

The species having been recorded from the Baltic (see p. 264), it was decided to see what would be the effect of growing the species in a medium of lowered salinity. It was found that in mixtures of Allen-Miquel sea water with distilled water growth was good at all concentrations up to $50 \%$ distilled water.

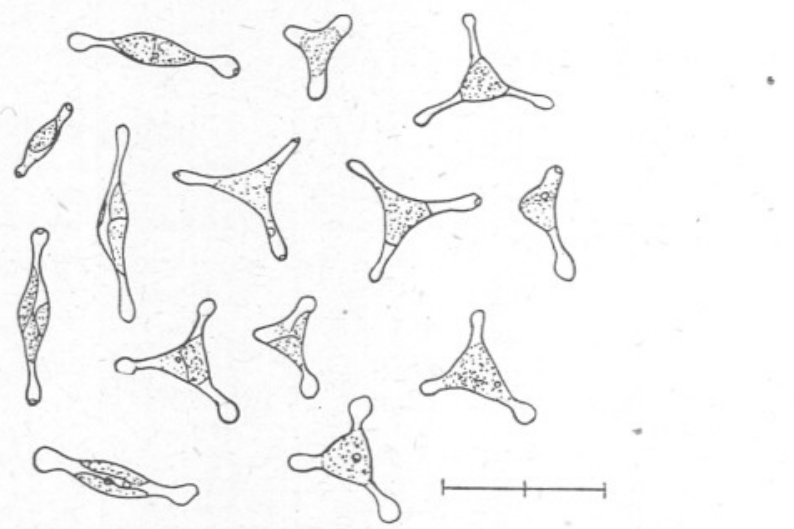

Fig. 7. Normal and triradiate cells with swollen extremities from cultures grown in a mixture of one part of normal Allen-Miquel sea water to three parts of fresh water. Each division of the scale represents 10 $\mu$.

There was some growth even with only $25 \%$ Allen-Miquel sea water. When the mixture contained only $5 \%$ of the latter no growth was visible. Thus the species can live and grow at salinities much lower than that of normal sea water, but not in fresh, or almost fresh, water.

An interesting feature of these experiments was the relatively large number of cells, both normal and triradiate, with much swollen tips to the arms. Some extreme, although common, examples are shown in Fig. 7. Other cells had 
swellings intermediate between these and normal cells, in which the enlargement of the tip is only just perceptible. It must be noted, however, that swollen tips are not confined to cells grown at lowered salinities but occasionally have also been seen in ordinary Allen-Miquel solutions, though not as commonly. The fact that they were present in the Allen-Miquel controls to these salinity experiments suggests that lowering the salinity merely accentuates a tendency to form swollen tips and is not in itself a primary causative factor. In connexion with this subject Hustedt (1930, p. 158) has mentioned that he found a size increase in marine diatoms with reduced concentration of the medium.

\section{Cruciform Cells}

The experience with lowered salinity serves to emphasize the great variability of cell form in this species, a variability that can rarely be attributed to some obvious condition of the environment. Cells of odd shape are not uncommon in most cultures, and from time to time even four-armed cells are seen; these

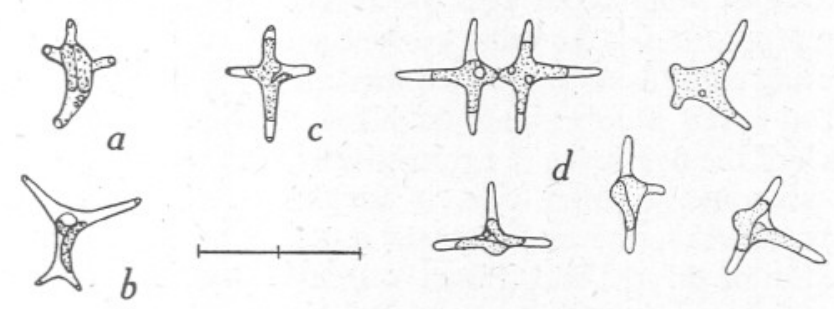

Fig. 8. Cruciform cells. $a, b$, irregular types; $c$, regular cruciform cell; $d$, a group of cruciform cells with one arm reduced; a division stage is shown in which the shortened arm of one daughter cell is a little smaller than that of the other. Each division of the scale represents ro $\mu$.

in healthy cultures about which there is nothing noticeably unusual. They are generally irregular in shape; two specimens are drawn in Fig. $8 a, b$. It is possible that for a time their descendants remain four-armed, but of the irregular cells division stages have not been observed. The shape is probably unstable, and it is likely that they die out or quickly revert to a smaller number of arms. Slides containing specimens have often been washed off into culture medium, but the shape has never been found again in the ensuing growth, even after much searching. As the cells were always noticed when under a cover-glass and when using a high-power objective it was not possible to pick them out individually.

It has already been mentioned that in February 1942 Dr Gross sent to me samples-of the cultures he maintained at Edinburgh. They had been derived from Plymouth stocks in 1937. From one of these samples two subcultures were started, one in Allen-Miquel sea water and one in Erdschreiber; they were maintained for a considerable period. They continued mainly free from triradiates although a few were always present in both media. In January I943, during a routine examination, there was noticed in these cultures, and 
more frequently in the Erdschreiber culture, cells in the form of a perfect cross (Fig. 8c), not an irregular four-armed structure like those mentioned in the preceding paragraph. In general, one arm was slightly longer than the other three, which were equal. The finding of several of these cells, all exactly alike, seemed to indicate that the type was relatively stable reproducing true to type. This was confirmed when they increased somewhat in abundance during the next few weeks and dividing pairs were seen. In April the first of a series of attempts to obtain the form in pure culture was made. Some of the culture containing crosses was diluted down with a large volume of sterile Allen-Miquel sea water and placed in Petri dishes in a north window. After some days clusters of cells were visible to the naked eye. The majority of the clusters had grown from single cells and were all of one type. It was just possible to distinguish the type with a $\frac{2}{3}$ in. objective and to find a few clusters which consisted entirely of crosses. They were picked out with fine pipettes and transferred to sterile media in small flasks. It was impossible to avoid picking up cells of other types with the crosses, but the latter nearly always formed a big proportion of the cells thus selected for further growth. Ten days after inoculating eight flasks in this manner three showed no signs of crosses, but five did so in fair numbers, although less than half the cells were of this type. In each of the five flasks the crosses were very similar in form; between flasks there was some variation, those in one flask, for instance, having shorter and stumpier arms than the crosses in the others. Three of these flask cultures were selected to be diluted and strewn in Petri dishes as before, the resulting clusters this time being, of course, more frequently cruciform, and were more readily picked out without admixture with other types. In spite, however, of repeated attempts a pure culture of crosses was never obtained, although on several occasions it was practically certain that nothing but crosses had been picked up by the pipette, except possibly for ovals mixed with, and probably produced from, the crosses. All the cultures started in this way with crosses and perhaps a few ovals soon had a big proportion of triradiates and normals, often of small stunted varieties which had probably arisen by reversion from the crosses, either directly or through the formation of oval cells. Cruciform cells with one, or even two, arms shortened have been seen (Fig. $8 d$ ) and suggest that this is one way in which they may change back to the triradiate or to the normal condition. Cruciform cells producing ovals have also been seen. The best cultures obtained were about $50 \%$ cruciform and this figure was not improved on. Indeed, in some series successive subcultures have shown a considerable diminution in the proportion of crosses present. The cross is evidently less stable in form than the triradiate, although it keeps its shape through what must be a very large number of generations.

By early 1945 in one series of cultures cruciform cells had become very rare and they showed signs of dying out altogether. In another series they were still frequent, but normal and triradiate cells were more numerous; in a third series cruciforms were very common although not so abundant as the other types. 
It is not easy to suggest how cruciform cells originate. They probably arise from oval cells which become four-cornered, in the same way that triradiates arise from three-cornered ovals. Such four-cornered ovals have not been seen, though this is hardly surprising as they must be very rare indeed. There seems to be no obvious explanation of why oval cells should occasionally become four-cornered.

The appearance of true cruciform cells was not confined to the cultures obtained from Dr Gross, although in them they were much commoner. Cells of identical appearance were seen very rarely in four other series of cultures from early I 943 until the end of that year; they had not previously been observed. The cultures in which crosses were seen, sometimes only one or two cells in each series, were Stock 589, Series II, Series III, and Series IV C. They were also seen again in May 1945, in Stock 569 and Series III. There is no question of contamination between these cultures or between them and those from Edinburgh; the cells must have arisen independently in each. In these cultures they never increased in abundance as they did in the cultures from Edinburgh; they probably died out as they have not been seen lately. It seems strange that crosses should have appeared in several cultures all about the same time. The cultures were all standing side by side subjected to the same temperature and lighting conditions, but one flask contained Erdschreiber as the medium, the others Allen-Miquel sea water. On the whole it does not seem satisfactory to attribute the occurrence of the crosses to physical or chemical conditions unless it be that all-round good cultural conditions are favourable to the production and survival of aberrant shapes, as they may well be. The cross is evidently a moderately stable form that now and again appears, though rarely, and in good cultural conditions can survive. The appearance of a very few specimens in several separate cultures in 1943 and again in 1945 must be regarded as coincidences.

Frustules with more than four arms have not been seen.

\section{Nomenclature}

The diatoms used in these experiments were all derived from the original cultures of Allen and Nelson. The stock series 589 has been traced back through Dr Allen's notes to a Petri dish inoculated on 5 December 1907 with plankton from outside the Sound. Stock series 569 does not occur in his notes and is probably derived from a flask of 589 in which the middle figure, written on the flask with a glass-marking pencil, had become partly rubbed away and later interpreted as a 6 when it was subcultured at some time before the cultures came into my keeping. There appears to have been no addition to the cultures from the sea, since the species was isolated before Allen and Nelson's I9Io paper was published.

The species was identified by Nelson (private information from Dr Allen) and the name Nitzschia closterium W.Sm. forma minutissima was given by him. 
As he quotes no authority for the forma it is not clear whence he derived the name; it may have been suggested by some then recent systematic papers. Mereschkowsky (I90I), for instance, discussing these difficult diatoms abandoned the name closterium, splitting the forms included under it into two new species which he called Nitzschiella tenuirostris and $N$. gracilis. Of the former, which corresponds most closely to what is generally regarded as Nitzschia closterium, he had several varieties, one of which, Nitzschiella tenuirostris var. parva Mer. forma minutissima is a minute diatom, 35-40 $\mu$ long. His figure of it shows a more swollen central portion and finer arms than those of our cultured species. Of his tenuirostris as a whole he remarked that the striae and carinal dots are invisible. Peragallo \& Peragallo (I897-I908, p. viii) discussed this classification of Mereschkowsky's without reaching any definite conclusion, but in the text of their systematic part they recorded closterium Ehr. as a variety of $N$. longissima though in the legend to their plate LXXIV they give it specific rank.

My own impression is that whilst the Nitzschia of these cultures is very close to $N$. closterium (Ehr.) W.Sm., it may well be specifically distinct, but that with our present inadequate knowledge of this extremely difficult group the possibility cannot be excluded that it is merely a 'phase' of that species in the sense in which Hendey (1937) uses the term. For the time being it may continue to be distinguished as forma minutissima in Nelson's sense until such time as the genus is thoroughly revised.

Some notes on $N$. closterium as it appears in the literature are relevant to this discussion. Ehrenberg (1840) described and figured as Ceratoneis Closterium n.sp. a diatom about $100 \mu$ long which he obtained in the

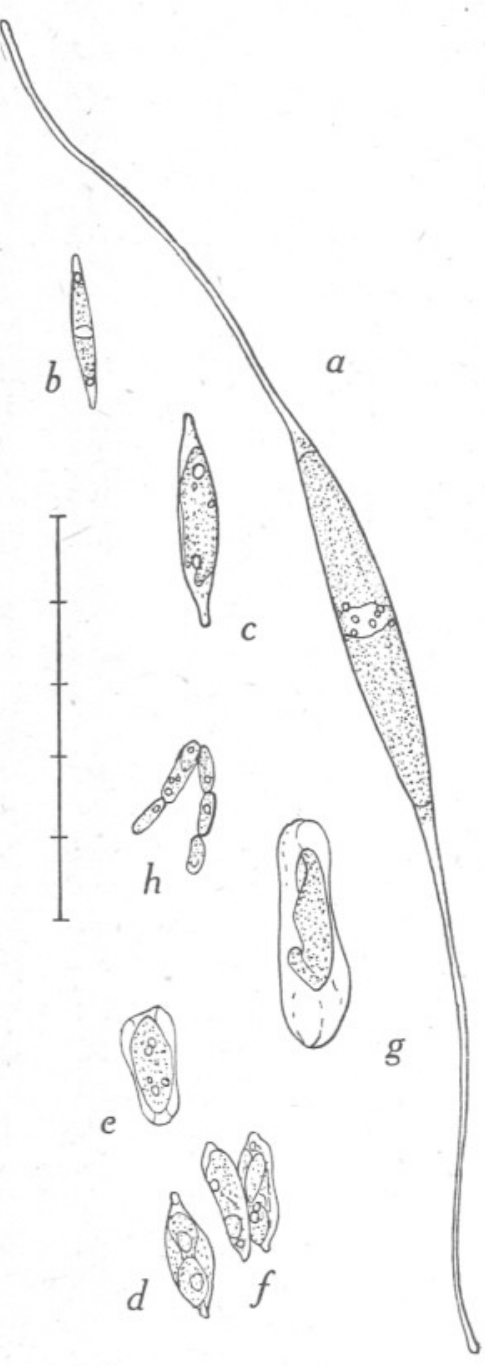

Fig. 9. Nitzschia (? closterium (Ehr.) W. Smith) from an aquarium tank. $a$, frustule from aquarium tank; $b, c$, reduced frustules after culturing; $d$, an 'oval'; $e, f$, division stages of 'ovals'; $g$, a large type of 'oval'; $h$, a string of small oval types. Each division of the scale represents $10 \mu$.

North Sea at Cuxhaven and elsewhere. His figure of three cells was copied closely (except as regards colouring) by Pritchard (I852). Smith(I853)described 
and figured as Nitzschia Closterium n.sp. what is apparently the same organism. $\mathrm{He}$ indicated a species about $\mathrm{I} 60 \mu$ long with definite striae (? carinal dots). Except for the striae, which I have not seen, his species resembles a Nitzschia common in Plymouth dredgings and which lives abundantly in some of our shallow tanks. A particularly fine specimen is shown in Fig. $9 a$, but the arms are often much shorter than this and curved in one direction only. Another figure of what seems to be the same species is given by Lebour (1930, fig. I76, p. 2I2). I disagree with the statement that 'it is the form used commonly by Dr Allen...for culture', in spite of the fact that the size she gives approaches, although it is considerably longer than, the cultured form. I have never seen a cultured Nitzschia in which the arms are so slender along their whole length and so markedly differentiated from the central part containing the chromatophores. Moreover, the manner in which the chromatophores are drawn in this figure agrees with the dredged and tank-living form much more closely than with the cultured type. The question arises, is the latter a modification of the former brought about by culturing?

To answer this question specimens from the aquarium were isolated into Allen-Miquel sea water and grown in the usual way. There was a marked tendency for the arms to shorten relatively and the cells to become dwarfed (Fig. $9 b, c$ ), but the frustules never came to resemble those of the regular cultures, the chromatophores especially differing in appearance. Cells even resembling ovals were produced (Fig. $9 d-h$ ) but they varied in size and were always distinctly different from ovals of the stock species, although they divided in a similar manner. Moreover, the aquarium species would not give dense cultures as does the stock species, indicating that its requirements as to $p \mathrm{H}$, etc., are not the same. Nothing resembling a triradiate was seen in these cultures of the aquarium form which seems to be very close to Smith's $N$. Closterium, and may indeed be the same species although the striae he mentions have not been seen. Van Heurck (I896) regarded Smith's species as a variety of $N$. longissima (Bréb.) Ralfs and gives the length as $260-320 \mu$. He remarked that 'the carinal dots are only visible with difficulty. It requires an excellent immersion objective to distinguish them clearly.... It was probably the carinal dots that Prof. Smith described as indistinct marginal striae.' Peragallo \& Peragallo (I897-I908), as we have seen, also regarded closterium as a variety of $N$. longissima; they said that the striae are invisible, and give the length as 26-I $40 \mu$. Their figure (pl. LXXIV, fig. I5) resembles the aquarium form more closely than the culture species. Karsten (1899) shows a figure (fig. I77) of $N$. closterium W.Sm. which resembles the aquarium species; he regards it as distinct from $N$. longissima (Bréb.) Ralfs, ascribing to it a length of $50-84 \mu$. Gran (I905) copies Karsten's figure and more or less his description. Hendey (1937) describes a species resembling the aquarium form with a length up to $80 \mu$. His figures do not suggest the cultured form. Hart (1942, p. 292) comments on the ubiquity and variability of the same species and mentions a very minute phase from the Antarctic 'which in fresh samples can often be 
seen to form chains of from three to twelve frustules'. Lucas (1940) has remarked on the association with Phaeocystis of a very slender variety of $N$. closterium 'at times so slender as almost to suggest the possibility of another species'. I have examined some of his material which he kindly sent at my request. His slender form seems to be nearer to the culture type than to the aquarium type but is on the whole longer $(40-70 \mu)$ than the former and also differs from it in the clearer separation of the chromatophores, in which respect it resembles the latter. Dr Lucas tells me that he has not observed triradiates in his North Sea material.

The only reference in the systematic literature which can fairly confidently be ascribed to the same species as that of the culture form is by Karsten (1905). His figure closely resembles the normal cell of the cultures. He identifies it as Nitzschia sp. and says it is like closterium but considerably smaller. It has two chromatophores and is about $23 \mu$ long.

\section{The Triradiate in Nature}

As Phaeodactylum-tricornutum n.g., n.sp., Bohlin (1897) has described and illustrated the triradiate form of Nitzschia. For this reference I am greatly indebted to Prof. Fritsch's unique knowledge of algological literature. Bohlin's description and figures of his Phaeodactylum agree in all particulars with the triradiate of the cultures, even to his chemical tests which I have repeated. Bohlin was puzzled as to the affinities of his organism and considered, on the basis of the chemical reactions of the cell and the plane in which it divides, that it stood near to the diatoms. He also considered that his Phaeodactylum might possibly be identical with Cerasterias raphidoides forma tridens (Reinsch, I867). Unfortunately, I have not been able to see a copy of Reinsch's work but it may be that Bohlin is mistaken because Cerasterias Reinsch (now included in Tetraëdron Kützing) is a genus of freshwater green algae. Bohlin's specimens appeared in cultures of another organism (Brachiomonas) which he had obtained from rock pools on some Baltic islands near Stockholm. The triradiate was evidently removed from the pools along with the much more abundant Brachiomonas, but a period of time was necessary for it to multiply in the culture before it became sufficiently numerous to be noticed. Nevertheless, this can be regarded as a record of the occurrence in nature of the triradiate.

In a later paper Bohlin (1902) stressed the similarity between his Phaeodactylon (as he now spelt it) and Centronella Reichelti Voigt, a triradiate freshwater alga, and proposed that Voigt's genus Centronella be suppressed and that his species be known as Phaeodactylon Reichelti. However, as I have shown, Phaeodactylon is the triradiate form of a Nitzschia, with which genus Centronella Voigt does not appear to be related. This seems clear from a study of Voigt's original paper (I902) and from Krieger (1927), who figures and describes two species of Centronella and gives several references not quoted 
here. Krieger regards Centronella as a diatom but Fritsch (1935, p. 607) considers that this is doubtful.

So far I have not myself succeeded in obtaining the triradiate direct from the sea, but Dr Mary Parke informs me that it was frequent in water samples from the Irish Sea off Port Erin, together with the normal form, sometimes being more abundant than the latter. There was no possibility of there being a mistake in identification because she was familiar with it in Nitzschia cultures derived from Plymouth. It has also been abundant in Loch Craiglin, Argyllshire, where it has been observed frequently by Dr S. M. Marshall and by Dr F. Gross. Dr Marshall kindly sent me a sample of the surface water from the Loch, and I was able to assure myself that the triradiates occurring there are identical in every respect with those in the cultures. It is perhaps noteworthy that the Loch is the scene of fertilization experiments, the water being treated with artificial fertilizers. There is, however, no reason to suppose that the presence of artificial fertilizers is necessary for their existence, although they may very well produce conditions favouring its multiplication.

Not far from Loch Craiglin, at Charsaig on the Atlantic coast of Argyll, is a fish-hatching tank which is filled from time to time with water from the open sea. Dr Marshall informs me that early in 1945 it was fertilized with phosphate and nitrate and that Nitzschia was observed in it. It later was emptied, washed down and refilled with water from the open sea, but not fertilized apart from the excretions of two hundred or more plaice kept in it and fed on mussels. About a fortnight after refilling, Dr Marshall noted that it was a thick soup of Nitzschia, both normal and triradiate, and she very kindly sent a preserved sample to me (mid-July I945). The Nitzschia presumably came from the sea, for at no time had a culture been added to the water in the tank.

The sample from the fish-hatching tank was of great interest; never have I seen so great a variation in cell shape. The normals were anything from straight to curved into an almost complete ring, the ends of the arms sometimes almost meeting; often the arms were bent in opposite ways to form an S-curve. The triradiates, which were extremely plentiful, varied very greatly also. All stages of arm reduction were to be seen; sometimes only a mere trace of the third arm remained. Cells with all three arms complete often had them bent at varying angles. No culture has ever shown such great diversity amongst its cells, but apart from this these Nitzschia from Charsaig agreed closely with the culture forms, except that possibly the arms were a trifle longer and a little more slender. There is no doubt they were the same species. From these observations from nature, few as they are, we cannot but conclude that the triradiate is a natural phase in the biology of the species.

\section{CONCLUSION}

The species of Nitzschia forming these cultures shows a degree of variability in shape which is surprising even for diatoms, and the different shapes have varying degrees of stability, the normal and triradiate in particular retaining 
their respective characteristics through many generations without passing one into the other. The cruciform is relatively less stable although it too will continue to multiply for a long period of time, though a fair proportion of the daughter cells appear to revert readily to one of the other types. The oval shape is often an intermediate stage between the other shapes, although they are not dependent on it for passing one into the other. Apart from the influence of light in stimulating the production of ovals nothing concrete is known as to there being any physical or chemical character of the environment capable of initiating these changes, although the marked autumnal tendency of the triradiates to shorten and lose one arm suggests that light, either intensity, or perhaps more likely length of day, is not without some influence. Nothing is known as to the relation of any of these changes to a sexual method of reproduction, which has not been seen in this species.

The comparatively great stability of some of the shapes raises some interesting reflections. If these shapes were to become fixed in the sense that they no longer changed one into another, and if each continued to multiply its own kind, there would arise forms entitled to be regarded as so many species. However, until we have more complete information, especially as to any sexual phases there may be, it is not possible to assess the degree of probability of this happening in the future.

A very interesting example parallel to the triradiate Nitzschia is recorded by Conger (1939) from the Crystal Lake, Wisconsin, where Fragilaria construens was found in tremendous abundance stratified in several middle layers of the bottom deposit, a high proportion being completely triangular or triradiate in shape. Dr Conger has very kindly sent me some of his material; in it can be found all stages in complete transition from the regular form of the species, elongate with swollen median portion, to completely triradiate forms, the intermediate stages showing a gradual bulging out of one side until a complete third arm (in the sense that this term has been used for Nitzschia) is produced. It is, of course, impossible to say whether these are stages in the production of a third arm or in its gradual disappearance. Many of the stages can be seen in the photomicrograph reproduced in Conger's plate I, fig. I.

With regard to the abundance of Fragilaria in the lake deposits Conger remarks: 'it shows that there must have been a considerable period at some time in the history of the lake when its waters "bloomed" for many successive years with this form. The presence in these particular samples of a high preponderance of mutant and abnormal forms of this species is also strongly suggestive of a radical transition stage in the history of the lake when conditions were not always too favourable, though this is in itself a variable species which may partially account for these mutants.' It seems to me equally likely that the production of the mutants may have been stimulated by conditions exceptionally favourable to the species at the time when it became so completely dominant. In the same way the production of triradiate Nitzschia in abundance may be an indication of conditions especially favourable to the multiplication 
of the species and the survival of aberrant forms. It has been shown by experiment that under good conditions triradiates can multiply more rapidly than normal cells, and the same seems to be true to some extent of cruciform cells. Thus certain strains of aberrant forms, under good conditions such as those of constant culturing, are better able to compete for nutrients than the more normal forms and to overtake them. When conditions are unfavourable normal forms are better able to survive than aberrant ones.

That the suggestion just advanced may be true is partly confirmed by changes in cultures which have stood neglected over a long period of time. Dr Lucas has recently informed me that after 194I the Hull cultures were irregularly subcultured until the spring of 1943 , and then, owing to pressure of other work, entirely neglected for over two years. When in the summer of I945 steps were taken to revive them the subcultures made from them showed a striking decrease in the percentage triradiate, especially when compared with corresponding Plymouth stocks which had been regularly subcultured and kept growing through the same period. The difference in August 1945 is expressed in Table VI, and is especially striking for the clone triradiates and

Table Vi. Percentage Triradiate of Hull and Plymouth Cultures, August I945

\begin{tabular}{|c|c|c|c|}
\hline Hull & triradiate & Plymouth & $\stackrel{\%}{\text { triradiate }}$ \\
\hline $\begin{array}{l}\text { Standard stock } \\
\text { (7 weeks later) } \\
\text { (subculture from last) }\end{array}$ & $\begin{array}{l}2 \cdot 74 \\
\mathrm{I} \cdot 26 \\
0.94\end{array}$ & $\begin{array}{l}\text { Stock } 569 \\
\text { Stock } 589\end{array}$ & $\begin{array}{l}9 \mathrm{I} \cdot 8 \\
77 \cdot \mathrm{I}\end{array}$ \\
\hline $\begin{array}{l}\text { Clone triradiate } \\
\text { (subculture from a I } 942 \text { culture) } \\
\text { (subculture from a I } 943 \text { culture) } \\
\text { (subculture from a } 1943 \text { culture) }\end{array}$ & $\begin{array}{r}2 \cdot 7 \\
32 \cdot 3 \\
22 \cdot 2\end{array}$ & $\begin{array}{l}\text { Clone triradiate, } \\
\text { Series III }\end{array}$ & 90.5 \\
\hline Clone normal & $\infty \circ \cdot 0$ & $\begin{array}{l}\text { Clone Normal: } \\
\text { Series I } \\
\text { Series II }\end{array}$ & $\begin{array}{l}74 \cdot 8 \\
67 \cdot 7\end{array}$ \\
\hline
\end{tabular}

normals, which were parts of the same clones kept respectively in Hull and Plymouth. It is possible that the great decrease in the percentage triradiate when subcultures are made from old exhausted cultures is due to some extent, at all events, to the gradual death of all kinds of armed cells and the survival only of ovals enveloped in a thick 'mucilaginous' coat. Such ovals, in a resting condition, are to be seen in old exhausted cultures and were abundant in these old Hull cultures, samples of which I was able to examine alive and to revive for myself with substantially similar results to those obtained at Hull. On adding fresh media resting ovals begin to divide again, and like all ovals eventually produce mainly the normal type of cell. It will be noted that the Hull subculture made from a 1942 culture of the clone triradiate had fewer triradiates in it than those made from a 1943 culture of the same clone.

In general it seems true that good cultural conditions are more productive of triradiates than bad or indifferent conditions, but there are exceptions. 
A possible explanation of some of these exceptions has already been advanced (p. 252), where it was suggested that strains of varying virility may arise, and that when a strong strain of triradiate appears in a culture it increases in abundance relative to the normal cells. An exception not readily explained, on the supposition that triradiates are most likely to become abundant under good cultural conditions, is the finding by Dobell (see p. 238) of large numbers of triradiates in old cultures left at the Royal College of Science. These triradiates also seem to have become abundant in an unusually short period of time, a matter of about six months only; perhaps there were already some in the cultures which Dr Allen took with him to London in that summer of I9IO. So long after the event it is no longer possible to make certain on these points.

Finally, there remains the possibility that in some strains of triradiate there is a greater tendency than usual to shorten the third arm, and that thereby a higher percentage than usual pass back into the normal condition. Something of this nature appears to be indicated by the figures for Series I and II (Table IV), where of the relatively small numbers of triradiates present a high proportion were short-armed, especially in Series II, and in correspondence with this it was long before triradiates in these cultures became at all common. When they did become common the proportion of short-armed cells to those fully triradiate was much less than it had been before.

It would be ungracious to conclude without recording the great interest the late Dr E. J. Allen, F.R.S., took in the earlier stages of this work and the benefit I derived from discussion with him. My grateful thanks are also due to the late Director, Dr Stanley Kemp, F.R.S., whose interest and encouragement were so helpful during the difficult years of the war. Correspondence with Dr C. E. Lucas at Hull has also been particularly stimulating. Other acknowledgements are made in the text.

\section{SUMMARY}

I. The natural history in culture of the species of Nitzschia originally isolated from the sea by Allen \& Nelson (I9IO) and grown at Plymouth and elsewhere ever since has been studied. It is shown that three main types of cell exist: normal with two arms (rostra), triradiate with three arms and ovals with none. Both normals and triradiates produce ovals by division, and the ovals so produced can multiply to form further ovals, or can grow either two or three arms, generally two, to form normal or triradiate cells.

2. Ovals are more readily produced under good lighting conditions than under weak illumination.

3. The cell wall is very lightly silicified, and the cells, unlike those of most diatoms, can elongate without auxospore formation. The maximum, and with it apparently the average, cell size of successive subcultures is variable.

4. When triradiates are present they may, and frequently do under good cultural conditions, multiply faster than normal cells and finally may almost 
completely dominate the cultures. Now and again a proportion of the triradiate cells shorten one arm and gradually pass, during successive divisions, into the normal condition. There is a greater tendency for this process to take place in the autumn than at any other time. There was a notable instance in November I94I when several cultures at Plymouth and at Hull simultaneously produced normals by this method on an extensive scale.

5. There is evidence that under unfavourable cultural conditions triradiates tend to be eliminated.

6. A cruciform type of cell has appeared occasionally in several cultures, but it has not been possible to obtain pure cultures of it, for the type appears to be somewhat unstable and readily reverts to the other forms. It has, however; persisted for a long time and for very many generations.

7. It is shown that the triradiate type occurs in nature, and there is no reason to suppose that it is an abnormal form due to culturing.

8. The nomenclature is discussed and it has been decided for the time being to retain the name Allen and Nelson originally gave to it, although there is a possibility that it is a species separate from Nitzschia closterium (Ehr.) W. Smith.

\section{REFERENCES}

Allen, E. J. \& Nelson, E. W., I9Io. On the artificial culture of marine plankton organisms. Fourn. Mar. Biol. Assoc., Vol. viII, pp. 42 I-74.

Barker, H. A., I935. Photosynthesis in diatoms. Archiv Mikrobiol. Zeitsch. Erforsch. Pflanzlich. Mikroorgan., Bd. vI, pp. I4I-56.

Bohlin, K., I897. Zur Morphologie und Biologie einzelliger Algen. Öfvers. Kongl. Vetenskaps-Akad. Forhandl. 1897. No. 9, pp. 507-29.

— I902. Centronella Voigt und Phaeodactylon Bohlin. Hedwigia, Bd. xLI, pp. (209)(2I0).

CONGER, P. S., I939. The contribution of diatoms to the sediments of Crystal Lake, Vilas County, Wisconsin. Amer. Fourn. Sci., Vol. 237, pp. 324-40.

EHRENBERG, C. G., I840. Über noch jetzt zahlreich lebende Thierarten der Kreidebildung und den Organismus der Polythalmien. Berlin, I840 and in Abhandl. Konig. Akad. Wiss. Berlin, I839 (I84I).

Fritsch, F. E., I935. The Structure and Reproduction of the Algae, Vol. I. Cambridge.

GeItler, L., I932. Der Formwechsel der pennaten Diatomeen (Kieselalgen). Archiv Protistenkunde, Bd. 78 , pp. I-226.

Gran, H. H., I905. Nordisches Plankton. XIX. Diatomeen.

Gross, F., I937. Notes on the culture of some marine plankton organisms. Fourn. Mar. Biol. Assoc., Vol. xxI, pp. 753-68.

Hart, T. J., I942. Phytoplankton periodicity in Antarctic surface waters. Discovery Reports, Vol. xxI, pp. 26I-356.

Hendey, N. I., I937. The plankton diatoms of the southern seas. Discovery Reports, Vol. xvI, pp. I5I-364.

HeUrCK, H. van, I896. A Treatise on the Diatomaceae. London.

HustedT, F., I930. Die Kieselalgen. Rabenhorst's Kryptogamen-Flora, Bd. vII, Teil $\mathrm{I}$.

Karsten, G., I899. Die Diatomeen der Kieler Bucht. Wiss. Meeresuntersuch. (N.F.), Abt. Kiel, Bd. IV, pp. 17-205. 
Karsten, G., I905. Das Phytoplankton des Antarktischen Meeres nach dem Material der deutschen Tiefsee-Expedition 1898-1899. Wiss. Ergebn. Deutsch. Tiefsee Exp. 'Valdivia'. Bd. II.

KRIeger, W. I927. Die Gattung Centronella Voigt. Ber. Deutsch. Bot. Ges., Bd. xLv, pp. $28 \mathrm{I}-90$.

Lebour, M. V., I930. The Planktonic Diatoms of Northern Seas. Ray. Society, London.

LUCAS, C. E., I940. Ecological investigations with the continuous plankton recorder: the phytoplankton in the southern North Sea, 1932-37. Hull Bull. Mar. Ecol., Vol. I, pp. 73-170.

Mereschkowsky, C., rgor. A list of Californian Diatoms. Ann. Mag. Nat. Hist., Ser. 7, Vol. vIr, pp. 474-80.

Peragallo, H. \& Peragallo, M., I897-1908. Diatomées marines de France et des districts maritimes voisins.

Pritchard, A., I852. A History of Infusorial Animalcules. London.

ReINsCH, P. F., I867. Die Algenflora des mittleren Theiles von Franken. Nürnberg.

Smith, W., I853. A Synopsis of the British Diatomaceae. London.

VoIGt, M., I902. Neue Organismen aus Plöner Gewässern. Forschungsber. Biol. Stat. Plön, Teil 8, pp. 33-46.

WIEDLING, S., I94I. A skeleton-free diatom. Botaniska Notiser.

- 1943. Die Gültigkeit der MacDonald-Pfitzerschen Regel bei der Diatomeengattung Nitzschia. Die Naturwissenschaften, I943, p. II5.

Wilson, D. P. \& LuCAs, C. E., I942. Nitzschia cultures at Hull and at Plymouth. Nature, Vol. I49, p. 33 I. 